\title{
Zjazd sędziów pokoju I okręgu pokojowego w Lublinie w latach 1876-1915 \\ (Ustrój, organizacja wewnętrzna $i$ obsada personalna)
}

\author{
Friedensrichterkongress des I. Friedensbezirks in Lublin \\ in den Jahren 1876-1915 \\ (Struktur, innere Organisation und Personalbesetzung)
}

1. Model sądownictwa rosyjskiego wprowadzony w Królestwie Polskim po reformie $1876 \mathrm{r}$. 2. Organizacja pionu sądownictwa pokojowego i zakres jego jurysdykcji. 3. Funkcjonowanie zjazdu sędziów pokoju oraz pozycja prezesa zjazdu. 4. I okręg pokojowy guberni lubelskiej - granice, struktura i zmiany na przestrzeni 40 lat. 5. Obsada etatowa zjazdu sędziów pokoju w Lublinie oraz jego siedziby. 6. Zasady finansowania lubelskiego zjazdu sędziów pokoju. 7. Sylwetki prezesów lubelskiego zjazdu sędziów pokoju oraz dodatkowych sędziów pokoju urzędujących przy zjeździe. 8. Obsługa kancelaryjna zjazdu, sekretarze zjazdu oraz komornicy urzẹdujący przy lubelskim zjeździe sędziów pokoju. 9. Ewakuacja na tereny Cesarstwa w 1915 r. i zakończenie dzialalności.

1. Modell des russischen Justizwesens, das in dern Polnischen Königreich nach der Reform 1876 eingeführt wurde. 2. Organisation der Friedensgerichtsabteilung und der Bereich seiner Jurisdiktion. 3. Funktionieren der Friedensrichterversammlung und der Rang des Vorsitzenden der Tagung. 4. Erster Friedensbezirk des Lubliner Gouvernements-Grenzen, Struktur und Änderungen in den 40-er Jahren. 5. Besetzungen Stellen der Friedensrichterverammlung in Lublin und ihre Sitze. 6. Prinzipien der Finanzierung des Lubliner Friedensrichterkongresses. 7. Silhouetten der Vorsitzenden und der zusätzlichen Richter des Lubliner Friedensrichterkongresses. 8. Kanzleibedienung des Kongresses, Sekretäre und Gerichtsvollzieher an der Lubliner Tagung der Friedensrichter. 9. Evakuierung ins Kaiserreich im Jahre 1915 und Schluss der Tätigkeit.

Dzieje wymiaru sprawiedliwości na ziemiach Królestwa Polskiego po reformie $1876 \mathrm{r}$. należą do tych obszarów historii prawa, które nadal wymagają dalszych badań naukowych. Mimo że problematyka ta znalazła już odzwierciedlenie we wspólczesnej literaturze historycznoprawnej w postaci dzieł prof. Artura Korobowicza, to nadal celowym wydaje się kontynuowanie prac $w$ tym kierunku, zwlaszcza $w$ odniesieniu do pionu sądownictwa 
pokojowego. Zróżnicowane formy organizacyjne, rozbudowana struktura sądownictwa pokojowego oraz jego miejsce w lokalnej spoleczności stanowią niezwykle wdzięczny przedmiot badań nad historią poszczególnych regionów. Niewątpliwą przeszkodą na tym polu badawczym jest stan i zawartość krajowych materiałów archiwalnych, które w większości przypadków wymagają żmudnej kwerendy lub pracy opartej na nieuporządkowanych zbiorach.

Założeniem autora niniejszego opracowania było ukazanie lubelskiego zjazdu sędziów pokoju $w$ aspekcie ustrojowo-organizacyjnym, a zarazem przez postacie osób, które swoją pracą kształtowały wizerunek i wpływały na ówczesną ocenę lubelskiego sądu. Dalszym celem realizowanym w najbliższej przyszlości będzie pokazanie dynamicznego obrazu funkcjonowania lubelskiego zjazdu sędziów pokoju na podstawie analizy biegu spraw sądowych i oceny poziomu orzecznictwa, w którym niejednokrotnie pojawial się zwyczaj sądzenia niektórych kategorii spraw w sposób sprzeczny z zasadami prawa materialnego i procesowego. Inspiracją dla badacza tej materii mogą być słowa Juliusza Benzefa wskazujące, że istnienie 21 zjazdów pokojowych $w$ Królestwie Polskim jest przede wszystkim powodem, że oprócz ogólnej jurysprudencji Departamentu Kassacyjnego i Izby Sqdowej opartej na prawie obowiazujacem, posiadamy tyle niemal specyalnych jurisprudencyj, ile jest zjazdów, a jurysprudencye te malo zreszta maja wspólnego z pogladami prawników na kwestye prawa, a nieraz wprost przepisom prawa sa przeciwne!.

Wielkie przemiany w Rosji w okresie ,odwilży posewastopolskiej” dotknęły również organizację wymiaru sprawiedliwości, który nie spelniał wymogów odpowiadających nowoczesnemu państwu. Nowy ustrój sądownictwa przewidywaly ustawy sądowe z 20 listopada/2 grudnia $1864 \mathrm{r}$. cesarza Aleksandra II, zakładające podział na piony sądownictwa ogólnego i sądownictwa pokojowego, które nie były ze sobą instancyjnie powiązane. Podział ten opieral się na założeniu oddzielenia jurysdykcji w sprawach mniejszej wagi, należącej do sądownictwa pokojowego, i w sprawach poważniejszych rozpatrywanych przez sądy ogólne. Pion sądownictwa pokojowego obejmowal wybieranych co do zasady sędziów pokoju oraz instancję apelacyjno-kasacyjną $w$ postaci zjazdu sędziów pokoju, $z$ wybieranym spośród sędziów pokoju prezesem. Nowe sądy wprowadzano stopniowo w kolejnych guberniach Imperium Rosyjskiego, zachowując niekiedy pewne odrębności od pierwotnego modelu zarysowanego w ustawach sądowych.

Rosyjskie ustawy sądowe z 1864 r. stały się również podstawą prac przygotowawczo-legislacyjnych nad wprowadzeniem nowych sądów w Królestwie Polskim. Nadrzędnym celem polityki rosyjskiej było ujednolicenie

1 J. B enzef, [rec.: A. Suligowski, Nowe sqady w Królestwie Polskim], „Gazeta Sądowa Warszawska" [dalej: GSW] 1886, nr 45, Literatura i krytyka, s. 718. 
sądownictwa Cesarstwa Rosyjskiego i Królestwa Polskiego, w którym dotychczas funkcjonował system oparty $w$ swym zalożeniu na francuskim modelu sądownictwa ${ }^{2}$. Efekt końcowy stanowiły akty prawne reformujące gruntownie ustrój sądownictwa w Królestwie Polskim, zatwierdzone przez cesarza Aleksandra II 19 lutego/3 marca 1875 r. i ogłoszone ukazem Senatu Rządzącego z $6 / 18$ marca $1875 \mathrm{r}^{3}{ }^{3} \mathrm{~W}$ ślad za tym wydano następne akty przygotowujące wprowadzenie reformy sądowej w życie. Na mocy ukazu z $26 \mathrm{maja} / 7$ czerwca 1875 r. podporządkowano sądownictwo Królestwa Polskiego Ministerstwu Sprawiedliwości Cesarstwa Rosyjskiego, a następny ukaz z 14/26 czerwca 1875 r. określał termin wejścia reformy w życie $\mathrm{z}$ dniem $1 / 13$ lipca $1876 \mathrm{r}^{4}$ Kolejne przepisy regulowały organizację prac przygotowawczych dotyczących wprowadzenia nowego ustroju sądownictwa i likwidacji dotychczasowej odrębności administracji sądowej Królestwa

${ }^{2}$ Przygotowanie reformy, polityczne jej przesłanki oraz przebieg prac legislacyjnych szczegółowo przedstawia A. Korobowicz, Sąownictwo Królestwa Polskiego 1876-1915, Lublin 1995, s. 15-79; t e nże, Reforma ustroju sqdownictwa w Królestwie Polskim po $1863 \mathrm{r}$., Przygotowanie $i$ treść, Lublin 1976; te nże, Komisja Prawnicza i pierwszy okres prac nad przygotowaniem reformy ustroju sqdownictwa $w$ Królestwie Polskim po powstaniu styczniowym, „Annales UMCS" 1976, sectio G, vol. XXIII, s. 199-223; te nż e, Przebieg prac legislacyjnych nad projektami reformy sqdownictwa w Królestwie Polskim po 1863 r., "Czasopismo Prawno-Historyczne" [dalej: CPH] 1977, t. XXIX, z. 2, s. 165-187; te nże, Wplyw czynników pozaprawnych na ksztalt reformy sqdowej w Królestwie Polskim z lat 1875-1876, CPH 1987, t. XXXIX, z. 2, s. 69-82; H. G r on i ow sk i, Walka Milutina z Bergiem (Spór o reorganizacje Królestwa Polskiego po roku 1863), „Kwartalnik Historyczny” 1962, R. LXIX, z. 4, s. 899-901.

${ }^{3}$ Były to: (1) postanowienie o zastosowaniu ustaw sądowych z 20 XI 1864 r. do Warszawskiego Okręgu Sądowego, tzn. ustawy o organizacji władz sądowych, ustawy postępowania karnego, ustawy postępowania cywilnego i ustawy o karach wymierzanych przez sẹdziów pokoju [dalej: postanowienie o zastosowaniu...], Zbiór Praw, t. VI, Warszawa 1881, s. 77-161; (2) ustawa o postępowaniach szczególnych w Warszawskim Okręgu Sądowym, Zbiór Praw, t. VI, s. 163-207; (3) przepisy o zastosowaniu do Warszawskiego Okreggu Sądowego ustawy notarialnej z 14/26 IV 1866 r., Zbiór Praw, t. VI, s. 207-221; (4) etaty wladz sądowych Warszawskiego Okreggu Sądowego, Zbiór Praw, t. VI, s. 222-243. Scalony tekst dwujęzyczny z zaznaczonymi przepisami, które nie obowiązują w Królestwie Polskim, zawierają Ustawy sqqdowe obowiqzujqce w gubernijach Królestwa Polskiego na mocy najwyżej zatwierdzonego 19 II/3 III $1875 \mathrm{r}$. postanowienia o zastosowaniu ustaw sqdowych z 20 XI 1864 r. do Warszawskiego Okregu Sadowego, t. I (organizacya sqdowa $i$ ustawa notarialna), t. II (ustawa postepowania sqdowego karnego $i$ ustawa o karach wymierzanych przez sędziów pokoju), t. III (ustawa postepowania sadowego cywilnego) $i$ Dodatki do ustaw sqdowych obowiqzujacych $w$ gubernijach Królestwa Polskiego, S. Petersburg 1875 (wyd. M. B. Wolfa). Oryginal w języku rosyjskim znajduje się w urzędowym zbiorze: Sobranije Uzakonienij i Rasporiażenij Prawitielstwa izdawajemoje pri Prawitielstwujuszczem Sienatie [dalej: SUiRP], 1875, nr 20, st. 254. Ukaz Senatu Rządzącego z 6/18 III 1875 r., Zbiór Praw, t. VI, s. 73-77.

${ }^{4}$ Zbiór Praw, t. VI, s. 315-317, 387-389. Ukazem Senatu Rządzącego z 14/26 VI 1875 r. ogłoszono najwyżej zatwierdzone $1 / 13$ VI $1875 \mathrm{r}$. postanowienie o sposobie wprowadzenia w wykonanie najwyżej zatwierdzonych 19 II/3 III 1875 r. praw o organizacji sądownictwa w Warszawskim Okręgu Sądowym, ibidem, s. 391-417. 
Poiskiego. Ostatnim formalnym krokiem ku unifikacji ustroju sądownictwa było zniesienie Komisji Rządowej Sprawiedliwości, na mocy zatwierdzonego 24 czerwca/6 lipca 1876 r. postanowienia Komitetu do spraw Królestwa Polskiego, które zostalo ogloszone jako obowiązujące 30 czerwca/12 lipca $1876 \mathrm{r}{ }^{5}$

1. Postanowienie z 19 lutego/3 marca 1875 r. przewidywało funkcjonowanie sądów gminnych, sędziów pokoju i zjazdów sędziów pokoju jako pionu sądownictwa pokojowego, oraz sądów okręgowych i Warszawskiej Izby Sądowej jako pionu sądownictwa ogólnego. Nad jednolitością orzecznictwa sądów niższych mial czuwać Senat Rządzący w Petersburgu jako najwyższy sąd kasacyjny. Postanowienie uchylało część przepisów zawartych w ustawie o organizacji władz sadowych z 20 listopada/2 grudnia $1864 \mathrm{r}$. oraz wprowadzało nowe szczególne regulacje ze względu na zastosowanie innych rozwiązań w Królestwie Polskim niż w Cesarstwie Rosyjskim ${ }^{6}$. Zrezygnowano z zasady wyboru sędziów pokoju, instytucji ław przysięgłych, ale także pozostawiono charakterystyczne dla realiów wsi polskiej sądy gminne (chociaż $w$ innej formie organizacyjnej niż wprowadzone w $1864 \mathrm{r}$.). Zmiany te wynikały $\mathrm{z}$ przesłanek społecznych, politycznych $\mathrm{i}-\mathrm{w}$ dalszej kolejności - $\mathrm{z}$ odmiennych warunków prawnych Królestwa Polskiego?.

Pion sądownictwa pokojowego wyróżniał się niezwykłą rozmaitością form organizacyjnych sądu. Mieścił się tutaj orzekający kolegialnie sąd gminny kierowany przez wybieranego - co do zasady - sędziego gminnego,

${ }^{5}$ Zbiór Praw, t. VIII, Warszawa 1882, s. 199-201, 389-391. A. K o r o bowicz, Sqdownictwo..., s. 48; W. Witk owski, Komisja Rzq̨dowa Sprawiedliwości w Królestwie Polskim 1815-1876, Lublin 1986, s. 272.

${ }^{6}$ Szeroko na ten temat: A. B e r e za, Das Modell der Friedensgerichtsbarkeit im Königreich Polen im Hintergrund des Russischen Reiches in den Jahren 1876-1915, [w:] Sachsen im Spiegel des Rechts, Ius Commune Propriumque, Böhlau verlag Köln, Weimar, Wein 2001, s. 355-370.

${ }^{7}$ Tym samym nowe sądy gminne zostały wprowadzone $w$ formie dotychczas nieznanej zarówno w Królestwie Polskim, jak i w Cesarstwie Rosyjskim. Dotychczasowe sądy gminne w Królestwie Polskim były ściśle powiązane z organami administracji gminnej i funkcjonowaly niezależnie od ogólnego systemu sądów. Trudno je również porównać do sądów „wołostnych” w Rosji, które miały charakter sądów stanowych przeznaczonych wyłącznie dla stanu włościańskiego, a więc jako sądy szczególne stały one poza systemem sądownictwa powszechnego. A. Korobowicz, Sqady gminne w Królestwie Polskim $w$ świetle reformy po powstaniu styczniowym, [w:] Gmina wiejska i jej samorzq̨d, red. H. Brodowska, Warszawa 1989, s. 243-244, 248. W projektach reformy pojawiały się propozycje nadania sądom gminnym charakteru sądów stanowych na wzór "sądów wołostnych" w Rosji, jednakże nie zostały one uwzględnione (A. Korob ow icz, W. Witk ow k i, Funkcje sqdowe organów adminisiracji lokalnej, CPH 1993, t. XLV, z. 1-2, s. 148; N. N. Jef r e mow a, Ministierstwo Justicyi Rossijskoj Impierii 1802-1917 gg., Moskwa 1983, s. 101; W. S pa sowicz, E. Piltz, Sqdownictwo w Królestwie Polskiem, [w:] Potrzeby spoleczne w Królestwie Polskiem, t. I, Kraków 1902, s. 56; W. S pasowicz, $O$ gminach $i$ sqqdach gminnych $w$ Królestwie Polskiem, [w:] Pisma, t. III, Petersburg 1892 , s. $352-353$ ). 
obok orzekającego jednoosobowo sędziego pokoju, urzędnika służby cywilnej pochodzącego $\mathrm{z}$ nominacji Ministra Sprawiedliwości. Instancją wyższą w okręgu pokojowym był zjazd sędziów pokoju reprezentowany $i$ kierowany przez pochodzącego $\mathrm{z}$ nominacji Ministra Sprawiedliwości prezesa zjazdu. Był sądem orzekającym kolegialnie $w$ kompletach złożonych $z$ prezesa zjazdu oraz zasiadających $w$ równej liczbie sędziów gminnych i sędziów pokoju $\mathrm{z}$ okręgu pokojowego ${ }^{8}$.

Nowo powstałe sądy rozpatrywały zarówno sprawy cywilne, jak i karne. Zlikwidowano tym samym podstawową zasadę organizacji dotychczasowego francuskiego systemu sądownictwa, zakładająca podział na oddzielne piony sądownictwa cywilnego i karnego. Zmiana ta oceniana była $w$ literaturze prawniczej jako słuszna $\mathrm{i}$ zgodna $\mathrm{z}$ postulatami ówczesnej nauki prawa ${ }^{9}$. Za niewątpliwy postęp uznano również skrócenie toku postępowania sądowego do dwóch instancji oraz przywrócenie instytucji kasacji (w procesie cywilnym i karnym) w kształcie zbliżonym do wzoru francuskiego. Postępowanie przed sądami pionu pokojowego zgodnie $\mathrm{z}$ duchem reformy było uproszczone, szybkie i pozbawione w dużej części formalizmu procesowego.

Sądy gminne sprawowały swoją jurysdykcję w nowo utworzonych okręgach sądów gminnych, które nie mogly liczyć więcej niż cztery gminy. W okręgu każdego sądu gminnego wybierany był przez zgromadzenie gminne sędzia gminny oraz co najmniej trzech lawników i ich zastępców na okres trzech lat. Wybranych na zgromadzeniach gminnych kandydatów na urząd sędziego gminnego gubernator przedstawial do zatwierdzenia (udzielając jednocześnie rekomendacji) Ministrowi Sprawiedliwości. Minister Sprawiedliwości mógł również mianować $\mathrm{w}$ trybie administracyjnym inne osoby, $\mathrm{z}$ pominięciem przedstawionych przez gubernatora kandydatów. Wybrani na lawników i zastępców byli natomiast zatwierdzani przez gubernatora $w$ porozumieniu $\mathrm{z}$ prokuratorem właściwego sądu okręgowego ${ }^{\mathrm{i0}}$.

${ }^{8}$ Ze względu na skład orzekający na posiedzeniach zjazdu być może właściwszą nazwą byłaby: zjazd sędziów pokoju i sẹdziów gminnych. Pozostałem jednak przy tradycyjnych określeniach znajdujących się w aktach prawnych, materiałach archiwalnych i ówczesnej prasie prawniczej, a więc: zjazd sẹdziów pokoju, zjazd pokojowy czy - chociaź rzadko - zjazdowy sąd pokoju. Na temat statusu urzędników sądowych patrz: A. B e r z a, G. S m y k, Stanowisko prawne urzedników administracyjnych i sq̨dowych w Królestwie Polskim po powstaniu styczniowym, CPH 2001, t. LIII, z. 1, s. 245-262.

"A. Suligow k i, O reformie sqdowej w Królestwie Polskiem, odb. z: „Niwa” [Warszawa] 1875 , s. 6.

${ }^{10}$ Szeroko na temat sądów gminnych palrz: A. B e r e z a, Obsada kadrowa sqdów gminnych w Królestwie Polskim w latach 1875-1915. Zasady prawne i praktyka, [w:] Dzieje wymiaru sprawiedliwości, red. T. Maciejewski, Koszalin 1999, s. 271-303; t e nże, Sady gminne powiatu zamojskiego w latach 1876-1915, ,Zamojskie Studia i Materiały” 2001, R. III, z. 1, s. 43-73; tenże, Sędzia gminny $w$ Królestwie Polskim $w$ latach 1876-1915 jako urzędnik slużby obywatelskiej, [w:] Administracja, zarzqdzanie i handel zagraniczny w warunkach integracji. Materialy Konferencyjne - Administracja, Krakowska Szkoła Wyższa im. Andrzeja Frycza Modrzewskiego, Kraków 2002, s. 11-48. 
Pochodzący z nominacji Ministra Sprawiedliwości sędziowie pokoju urzẹdowali w miastach, sprawując swoją jurysdykcję w rewirach (cyrkułach). Obszar rewiru obejmował najczęściej całe miasto $w$ jego granicach administracyjnych lub dwa miasta, jeżeli tyle znajdowało się na terenie jednego powiatu. Jedynie w niektórych stolicach guberni rewir obejmował część miasta $^{11}$.

$\mathrm{Na}$ sądownictwie pokojowym spoczywal obowiązek rozpoznania spraw mniejszej wagi, dlatego w jego orzecznictwie nie znajdziemy spektakularnych procesów, o których pisała ówczesna prasa. Jednakże liczba spraw, jaka była rozstrzygana przez instancje pokojowe, wskazuje na niezwykle ważną rolę, jaką sądy te spelniały w funkcjonowaniu wprowadzonego w $1876 \mathrm{r}$. modelu sądownictwa rosyjskiego. Nie były to jednak sprawy tak błahe, jeżeli znajdowały niekiedy swój final na forum Senatu Rządzącego w Petersburgu.

W zakresie jurysdykcji karnej podlegały im przestępstwa określone w ustawie o karach wymierzanych przez sędziów pokoju, zagrożone karą napomnienia, przestrogi, nagany, grzywny do 300 rubli, aresztu do trzech miesięcy i więzienia do jednego roku. W postanowieniu z 19 lutego/3 marca 1875 r. przewidziano jednak szereg wyłączeń - czy to ze względu na osobę $e^{12}$, czy na karę dodatkową przewidzianą za takie przestępstwa przez ustawę o karach wymierzanych przez sędziów pokoju ${ }^{13}$. Ponadto art. 76 postanowienia z 19 lutego/3 marca 1875 r. zawieral szereg wyłączeń natury przedmiotowej dotyczących przestępstw określonych $w$ art. 31, pkt 2, 38, $47,63,104,135,136$ i 142 ustawy o karach wymierzanych przez sędziów

${ }^{11}$ Ten stan rzeczy z czasem uległ zmianie gdyż pojawily się miasta powiatowe (np. Lódź) podzielone na kilka rewirów sędziów pokoju. W $1890 \mathrm{r}$. Ministerstwo Sprawiedliwości zostało podzielone na dwa departamenty. Sprawy dotyczące obsady personalnej instancji pokojowych były roztrząsane w II Departamencie Ministerstwa Sprawiedliwości; N. N. Jefremowa, Ministerstwo..., s. 76 i $79-80$.

${ }^{12}$ Nie podlegali sądom gminnym i sędziom pokoju wojskowi pozostający w czynnej służbie w oddziałach stacjonujących $w$ Królestwie Polskim oraz urzędnicy miejscowej administracji cywilnej i policji. Podlegały natomiast sądownictwu pokojowemu w Królestwie Polskim wykroczenia wojskowych $\mathrm{z}$ innych okręgów wojskowych; F. Fil o ch ow ski, [rec.: Łomnowski, Ustaw o nakazanijach, nalogajemych mirowym sudiami. Rukowodstwo dla mirowoj justicyi Carstwa Polskogo, Warszawa 1887], GSW 1888, nr 25, Literatura i krytyka, s. 416-417. Pewne ograniczenia natury podmiotowej dotyczyły również osób duchownych (zakonników, księży i diakonów) - art. $218 \mathrm{i}$ art. 1017-1029 ustawy postępowania karnego oraz cudzoziemców korzystających z immunitetu dyplomatycznego - art. 229 i 230 ustawy postępowania karnego.

${ }^{13}$ Wyłączenie jurysdykcji sądownictwa pokojowego miało miejsce wówczas, gdy ustawa o karach wymierzanych przez sędziów pokoju przewidywała karę dodatkową w postaci zesłania, zakazu prowadzenia działalności handlowej lub produkcyjnej, zamknięcia przedsiębiorstwa, oraz gdy powództwo o odszkodowanie za straty powstałe w wyniku przestępstwa przekraczało wartość 250 rubli - art. 74 i 75 postanowienia o zastosowaniu... 
pokoju ${ }^{14}$. Ważnym wyłączeniem - ze względu na ich dużą liczbę - były również przestępstwa przeciwko cudzej własności, jeżeli wartość przywłaszczonego lub skradzionego mienia przekraczała 30 rubli $^{15}$.

Od wyroków karnych sędziów pokoju i sądów gminnych przysługiwała stronom apelacja do zjazdu sędziów pokoju. Orzeczenie kary upomnienia lub przestrogi, nagany, kary grzywny do 15 rubli oraz aresztu do trzech dni przez sąd gminny lub sędziego pokoju miało charakter wyroku ostatecznego, na który przysługiwała jedynie skarga kasacyjna do zjazdu sędziów pokoju. Jeżeli na skutek przestępstwa powstała szkoda, wyrok karny dotyczący tego występku miał charakter wyroku ostatecznego tylko wtedy, gdy odszkodowanie z tytułu wynagrodzenia za szkodę powstałą na skutek przestępstwa nie przekraczało kwoty 30 rubli $^{16}$.

W sprawach cywilnych do właściwości sądów gminnych i sędziów pokoju należały spory $\mathrm{z}$ tytułu zobowiązań osobistych, umów i majątku ruchomego, których wartość nie przekraczała 250 rubli. Do tej wysokości rozpoznawane były również powództwa o odszkodowanie. Ponadto rozpoznawane były powództwa posesoryjne (jeżeli od momentu zakłócenia posiadania nie minęło 6 miesięcy) oraz powództwa o nadużycia prawa własności, uniemożliwiające korzystanie ze służebności (jeżeli od momentu zakłócenia korzystania ze służebności nie minął rok). W tym ostatnim wypadku nie dotyczyło to sporów o służebności leśne i pastwiskowe ustanowione na mocy ukazów uwłaszczeniowych, których rozpoznanie - do czasu wydania odpowiednich przepisów - należało do władz włościańskich ${ }^{17}$. Spod zasięgu

${ }^{14}$ Były to: obelgi czynne wobec urzędników policyjnych, sądowych, administracyjnych oraz stróżów polnych i leśnych w trakcie wykonywania przez nich obowiązków służbowych (art. 31 pkt 2); kłótnie, bójki i inne zaburzenia w miejscu publicznym $z$ udziałem tłumu zmuszające do użycia przemocy w celu zaprowadzenia spokoju (art. 38); urządzenie loterii bez wymaganego zezwolenia i niedozwolona prawem sprzedaż biletów loterii zagranicznej (art. 47); samowolne opuszczenie miejsca zesłania wskazanego orzeczeniem sądowym lub decyzja władzy administracyjnej (art. 63); wykonywanie dla zysku praktyki lekarskiej bez wymaganego zezwolenia, jeżeli skutkiem tej czynności był uszczerbek na zdrowiu pacjenta (art. 104); zamierzone obelgi czynne $w$ miejscu publicznym lub na zgromadzeniu oraz obelgi i potwarz (pisemna, ustna) wobec niespokrewnionej $z$ obwinionym $w$ linii wstępnej osoby starszej, mającej prawo do szczególnych jego względów (art. 135 i 136); samowolność oraz użycie przemocy (art. 142).

is Były to przestępstwa: kradzieży drzewa z lasu (art. 154-156), dewastacji lasu (art. 158), kradzież rzeczy (art. 169-172), oszustwo (art. 173-176) i przywłaszczenie lub strata rzeczy powierzonej (art. 177).

${ }^{16}$ Art. 86 postanowienia o zastosowaniu... Patrz szerzej: A. B a r zk i, Ostateczne wyroki sedziego pokoju $w$ sprawach karnych, GSW 1889, nr 10, s. 145-146.

17 Art. 115 postanowienia o zastosowaniu...; Podręcznik dla sq̨dów gminnych Królestwa Polskiego, ułożony przez W. Miklaszewskiego, A. Okolskiego i S. Budzińskiego, t. I, s. 149-155. Spory powstałe $z$ tabel likwidacyjnych i tytułów nadań na podstawie ukazów z 19 II/3 III 1864 r. i 28 X/10 XI 1866 r. dotyczących własności gruntów, korzystania ze służebności i prawa połowu ryb rozpoznawano nadal przed rosyjskimi organami do spraw 
jurysdykcji cywilnej sądownictwa pokojowego wyłączono większość spraw dotyczących nieruchomości i spory, w których zainteresowane były zarządy skarbowe (tzn. Skarb Państwa, Dwór Cesarski, wszystkie instytucje rządowe oraz kościoły i klasztory), a także wynikające $\mathrm{z}$ prawa wynalazczego ${ }^{18}$.

Podobnie jak w sprawach karnych określono kategorię orzeczeń cywilnych, które wydane przez sąd gminny lub sędziego pokoju miały charakter wyroku ostatecznego. Dotyczyło to spraw, w których wartość przedmiotu sporu nie przekraczała 30 rubli $^{19}$. W tym wypadku przysługiwała stronom jedynie kasacja do zjazdu sędziów pokoju. Charakter ostateczny miał również wyrok cywilny, jeżeli sędzia pokoju lub sąd gminny rozpoznawał sprawę według sumienia na wyraźne żądanie stron. W takiej sytuacji sądy I instancji pionu pokojowego działały w charakterze sądu polubownego i mogły tym samym rozstrzygać sprawy wykraczające nawet poza zakres ich jurysdykcji. Oczywiście nie dotyczyło to spraw wyłączonych spod właściwości sądu polubownego ${ }^{20}$.

Do kompetencji sądownictwa pokojowego należało również szereg innych spraw (prawo poświadczania aktów prywatnych na sumę nie przekraczającą 500 rubli w miejscowościach, gdzie nie było notariusza) czy sporów wymienionych w ustawach szczególnych (np. sprawy dotyczące naruszenia przepisów o polowaniu z 17/29 lipca 1871 r. $)^{21}$. Rozlegle kompetencje sądów pionu

włościańskich, tzn. komisarzem włościańskim, urzędem gubernialnym do spraw włościańskich i działającą przy MSW Tymczasową Komisją do Spraw Włościańskich Królestwa Polskiego. Tryb rozpoznawania tych spraw regulowało zatwierdzone $21 \mathrm{~V} / 2$ VI $1876 \mathrm{r}$. postanowienie Komitetu do spraw Królestwa Polskiego [dalej: KdsKP], Zbiór Praw, t. VIII, Warszawa 1882, s. 281-285. Patrz również: Zbiór ustaw wlościańskich obowiqzujacych w Królestwie Polskiem (z komentarzem F. Brodowskiego i J. Kaczkowskiego), Warszawa 1918, s. 185-194.

${ }_{18}$ Art. 117 postanowienia o zastosowaniu...; Podręcznik dla sqqów gminnych..., t. I, s. 161-165. Art. 9 przepisów o rozdzieleniu pomiędzy władze sądowe i urzędników Warszawskjego Okręgu Sądowego niektórych obowiązków dawnych sądów i urzędników sądowych guberni Królestwa Polskiego z 6/18 VIII 1876 r., Zbiór praw, t. IX, s. 223; Archiwum Państwowe w Lublinie [dalej: APL], Rząd Gubernialny Lubelski [dalej: RGL] A II 1876: 150, Kopia dziennika posiedzeń KdsKP z 20 VII 1876 r., k. 2-3; Postanowienie Komitetu Urządzającego z 30 XII $1865 \mathrm{r}$./11 I $1866 \mathrm{r}$. W celu wykonania art. 19 ukazu o urządzeniu włościan z 19 II/3 III 1864 r., Dziennik Praw Królestwa Polskiego [dalej: DPKP], t. 64, s. 388 i n.).

19 Art. 128 postanowienia o zastosowaniu... i art. 134, 156 i 162 ustawy postępowania cywilnego.

${ }^{20}$ Art. 30 ustawy postępowania cywilnego: Podrecznik dla sąów gminnych..., t. I, s. 159-161. Przepis uchylony na mocy najwyżej zatwierdzonego zdania Rady Państwa [dalej: NZZRP] 21 XII 1887 r. (SUiRP 1888, nr 10, st. 61), lecz uprawnienia w zakresie sądownictwa polubownego pozostały w nowej redakcji art. 1368 ustawy postępowania cywilnego sądowego; GSW 1888, nr 9, s. 143. Patrz również A. Suligowski, $O$ reformie sqdowej..., s. 9.

${ }^{21}$ Art. 10, 12 przepisów o rozdzieleniu pomiędzy władze sądowe i urzędników Warszawskiego Okręgu Sądowego niektórych obowiązków dawnych sądów i urzędników sądowych guberni Królestwa Polskiego z 6/18 VIII 1876 r., Zbiór praw, t. IX, s. 223-225. Podrecznik dla sq̨ów pokoju Królestwa Polskiego zawierający wszystkie te postanowienia, którymi winny sie kierować 
pokojowego poszerzaly dodatkowo uprawnienia $z$ zakresu jurysdykcji niespornej, zwłaszcza w zakresie postępowania spadkowego, opiekuńczego i wieczystoksięgowego.

2. Instancją apelacyjno-kasacyjną od orzeczeń sądów gminnych i sẹdziów pokoju funkcjonujących w okręgu pokojowym był zjazd sędziów pokoju. Okręg pokojowy dzielił się na okręgi sądów gminnych oraz rewiry sẹdziów pokoju (wyjątkiem był okręg pokojowy dla miasta Warszawy, gdyż na terenie miasta urzędowali wyłącznie sędziowie pokoju).

$\mathrm{Na}$ czele zjazdu sędziów pokoju stał prezes, który pełnił obowiązki stałego członka zjazdu. Byl on mianowany, zwalniany i przenoszony na inne miejsce urzędowania, na mocy decyzji wydawanej przez Ministra Sprawiedliwości $\mathrm{w}$ porozumieniu $\mathrm{z}$ general-gubernatorem warszawskim. Zrezygnowano w tym wypadku $\mathrm{z}$ obowiązującej w Rosji zasady wybieralności prezesa zjazdu spośród sędziów pokoju ${ }^{22}$.

Osoba prezesa zjazdu musiała czynić zadość warunkom, jakie były wymagane przy nominacji na urząd sędziego pokoju. Podobnie jak każdy sędzia pokoju składał on po otrzymaniu nominacji przysięgę przed duchownym właściwego wyznania na publicznym posiedzeniu wydziałów włásciwego sądu okręgowego. Zasada nominacji prezesa zjazdu sędziów pokoju nie spotkała się z taką krytyką, jak miało to miejsce przy sędziach pokoju. Wychodzono $z$ założenia, że zjazd sędziów pokoju, sądzący jako instancja apelacyjno-kasacyjna, powinien odzwierciedlać $w$ osobie prezesa element prawniczy, stojący ponad stosunkami miejscowymi reprezentowanymi przez zasiadających na posiedzeniach zjazdu pokojowego sędziów gminnych $^{23}$.

Do obowiązków prezesa jako stałego członka zjazdu należało reprezentowanie zjazdu sędziów pokoju w przerwach pomiędzy posiedzeniami oraz przeprowadzenie czynności przygotowawczych w sprawach zaskarżonych do

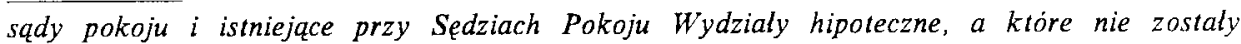
pomieszczone w "Podreczniku dla squów gminnych Królestwa Polskiego" z objaśnieniami F. Jeziorańskiego, Warszawa 1878 , s. 369-385; N. R e jn k e, Oczerk zakonodatielstwa Carstwa Polskogo (1807-1881), S. Peterburg 1902, s. 179-180; Art. 3 przepisów o zastosowaniu do Warszawskiego Okręgu Sądowego ustawy notarialnej z 14/26 IV 1866 r., Zbiór Praw, t. VI, s. 207. Patrz również wyrok Senatu Rządzącego z 7/20 V 1908 r., GSW 1909, nr 46, s. 705.

${ }^{22}$ I. G. Szarkow, Mirowoj sudia $w$ doriewolucyionnoj Rossii, "Gosudarstwo i Prawo" [Moskwa] 1998, No 9, s. 81; N. N. Jefremowa, Ministerstwo..., s. 70.

${ }^{23} \mathrm{~W}$ literaturze prawniczej znajdujmy nawet postulat mianowania prezesa zjazdu sędziów pokoju spośród prawników zamieszkujących inne okręgi pokojowe; W. Miklas zewsk i, Rys organizacyi wladz sqdowych podlug ustaw z 20 listopada 1864 r. i postanowienia o wprowadzeniu reformy sqdowej $w$ Królestwie Polskiem $z$ dnia 19 lutego 1875 r., Warszawa 1876, s. 143. 
zjazdu sędziów pokoju24. Ponadto czuwal on nad porządkiem kancelaryjnym, przyjmował codziennie ( $z$ wyjątkiem dni świątecznych $i$ galowych) prośby i odwołania oraz podpisywal wszelką korespondencję zjazdu sędziów pokoju. Pisma urzędowe pochodzące od niego posiadały okrągłą lakową (czerwoną lub ciemnoczerwoną) pieczęć z godłem Cesarstwa w środku i biegnącym wokół napisem, np.; Priedsied. Mir. Sjezda l-go Lubl. Gub.

Prezes wyznaczal miejsca sprzedaży majątków nieruchomych, według swojego uznania, albo w siedzibie zjazdu sędziów pokoju, albo w sądzie gminnym, w którego okręgu znajdował się sprzedawany majątek, oraz uczestniczył osobiście w czasie licytacji2 ${ }^{25}$. Przeprowadzał coroczną nadzwyczajną rewizje ksiąg stanu cywilnego osób wyznania rzymskokatolickiego prowadzonych $w$ parafiach ${ }^{26}$. Mógł również uczestniczyć w posiedzeniach sądu okręgowego, gdy zachodziła konieczność skompletowania składu orzekającego $^{27}$. Przekazywal do Ministra Sprawiedliwości sprawozdania z działalności wszystkich sądów funkcjonujących w okręgu pokojowym, nad którymi sprawował nadzór administracyjny ${ }^{28}$.

Prezes zjazdu sędziów pokoju mianował:

- sekretarza zjazdu (ewentualnie jego pomocnika) odpowiedzialnego za porządek w aktach sądowych zjazdu sędziów pokoju ${ }^{29}$;

${ }^{24}$ Do takich czynności należało np. przyjmowanie wyjaśnień od strony przeciwnej w razie złożenia apelacji od nieostatecznych wyroków sądów pokoju i sądów gminnych (art. 150 ustawy postępowania karnego), czy też przyjmowanie skarg i protestów na wyroki ostateczne (art. 175 ustawy postępowania karnego).

${ }^{25}$ Zbiór Praw, t. XVI, NZZRP z 27 XI/ 9 XII 1879 r., Warszawa 1884, s. 287-289. Problemy związane $\mathrm{z}$ pozycją prezesa zjazdu sędziów pokoju $w$ czasie licytacji i później W trakcie czynności policytacyjnych przedstawil W. Dudziński, Kilka slów o sprzedaży majqtkow nieruchomych przy zjazdach i sqdach gminnych, GSW 1883, nr 14, s. 214-216, nr 30, s. $469-472$.

${ }^{26}$ Art. 2 przepisów o rozdzieleniu pomiędzy władze sądowe i urzẹdników Warszawskiego Okręgu Sądowego niektórych obowiązków dawnych sądów i urzẹdników sądowych guberni Królestwa Polskiego z 6/18 VIII 1876 r., Zbiór praw, t. IX, s. 219-221; W. Now a k owsk i, Po latach dwudziestu, GSW 1893, Numer Jubileuszowy z 5 IV 1893 r., s. 219.

${ }^{27}$ Takie uprawnienie $w$ Cesarstwie posiadali honorowi sędziowie pokoju. Ze względu na ich brak (art. 6 postanowienia o zastosowaniu...) w Królestwie Polskim, uprawnienie do uczestnictwa w posiedzeniach sądu okręgowego w celu skompletowania składu sędziowskiego $z$ honorowego sẹdziego pokoju (art. 146 ustawy o organizacji władz sądowych...) przeniesiono na prezesa zjazdu sędziów pokoju (art. 53 postanowienia o zastosowaniu...).

${ }^{28}$ Przepisy o sposobie sporządzania i dostarczania do Ministeryum Sprawiedliwości od 1/13 I 1877 r. wiadomości statystycznych o prowadzeniu spraw karnych dotyczące formy tego sprawozdania na wniosek Ministra Sprawiedliwości ogłoszone ukazem Senatu Rządzącego z 11/23 XII 1876 r., Zbiór Praw, t. X, Warszawa 1882, s. 223-227. Forma sprawozdania dotycząca ruchu spraw karnych ustalona w 1876 r. zmieniała częściowo przepisy zatwierdzonego postanowienia z 11/23 XI 1871 r. o sprawozdaniach sądowych w sprawach karnych.

${ }^{29}$ Art. 59 ustawy o organizacji władz sądowych... 
- komorników i woźnych funkcjonujących przy zjeździe sędziów pokoju ${ }^{30}$;

- pisarzy sądowych w sądach gminnych - na wniosek sędziego gminnego, lub jeżeli przedstawiony kandydat był nieodpowiedni, to wedhug swojego uznania ${ }^{31}$;

- sekretarzy wydziałów hipotecznych na wniosek sędziego pokoju ${ }^{32}$;

Wszyscy wyżej wymienieni urzędnicy podlegali dyscyplinarnie prezesowi zjazdu sędziów pokoju, który nad nimi sprawowal nadzór ${ }^{33}$.

Komornicy i woźni funkcjonujący przy zjeździe sędziów pokoju byli etatowymi niższymi urzędnikami sądowymi. Komornik przeprowadzał czynności urzędowe w postępowaniu egzekucyjnym, składając $\mathrm{z}$ nich coroczne sprawozdanie do zjazdu sędziów pokoju. Woźny pełnil służbę audiencjonalną w czasie posiedzeń zjazdu. Do jego obowiązków należało również doręczanie stronom wezwań sądowych i pism procesowych. Było to rozwiązanie odbiegające od organizacji sądownictwa w Rosji, gdzie instytucja woźnego nie była znana, zaś wszystkie czynności należące do zakresu jego obowiązków obarczały komorników.

Zjazd sędziów pokoju zbieral się - ze względu na kryterium rzeczowe rozpoznawanych spraw - na posiedzeniach sądowych i porządkowych (inaczej ekonomicznych) $^{34}$. Na posiedzeniach zjazdu sędziów pokoju przewodniczył prezes zjazdu sędziów pokoju. W czasie wakowania tego stanowiska (z powodu śmierci lub zakończenia shużby), nieobecności lub choroby, obowiązki jego pełnił dodatkowy lub rewirowy sędzia pokoju urzędujący w mieście będącym siedzibą zjazdu sędziów pokoju ${ }^{35}$. W razie nagromadzenia znacznej liczby spraw, zjazd sędziów pokoju mógł podzielić się na odrębnie orzekające samodzielne wydziały. Wtedy w pierwszym $\mathrm{z}$ nich przewodniczył prezes zjazdu, zaś w drugim - sędzia pokoju miasta, w którym zbieral się zjazd sẹdziów pokoju ${ }^{36}$.

$\mathrm{Na}$ posiedzeniach sądowych orzekającego kolegialnie zjazdu sędziów pokoju - oprócz prezesa - zasiadali w równej liczbie sędziowie pokoju i sędziowie gminni; prawie zawsze było dwóch sędziów pokoju i dwóch sędziów gminnych. Kolejność uczestnictwa w posiedzeniach sędziów pokoju i sędziów gminnych była ustalona $w$ wykazie ułożonym przez prezesa

${ }^{30}$ Art. 49,60 i 62 postanowienia o zastosowaniu... w związku z art. 61-62 i 332 ustawy o organizacji władz sądowych...

31 Art. 23 postanowienia o zastosowaniu...

32 Art. 72 postanowienia o zastosowaniu...; W. H., Wydzialy hipoteczne powiatowe, GSW 1895, $\mathrm{nr} 41$, s. 643.

${ }^{33}$ Praktyka w zakresie kontroli nad sekretarzami wydziałów hipotecznych była różna w poszczególnych okręgach pokojowych Królestwa Polskiego. W niektórych okręgach pokojowych byli oni kontrolowani tylko przez sędziów pokoju.

${ }^{34}$ W. Miklas zewski, Rys organizacyi..., s. 49-52.

${ }^{35}$ Art. 37 postanowienia o zastosowaniu...

${ }^{36}$ Art. 55 ustawy o organizacji władz sądowych... i art. 44 postanowienia o zastosowaniu... 
zjazdu $^{37}$. Obligatoryjna na posiedzeniach była również obecność sekretarza zjazdu lub osoby zastępującej sekretarza ${ }^{38}$. Na posiedzeniach zjazdu sędziów pokoju mógł zawsze uczestniczyć pomocnik (towarzysz) prokuratora wyznaczony przez prokuratora miejscowego sądu okręgowego. Obowiązek taki ciążył na nim jedynie w wypadkach wskazanych $w$ prawie procesowym $^{39}$. Zjazd mógł sądzić nie tylko w swojej siedzibie, ale także w innym miejscu podległego mu okręgu, jeżeli uznał to za potrzebne dla wyjaśnienia sprawy.

Ważna rolę $w$ organizacji sądownictwa $w$ okręgu pokojowym spełniały posiedzenia porządkowe zjazdu sędziów pokoju odbywające się przy drzwiach zamkniętych, w analogicznym składzie jak posiedzenia sądowe. Prezes zjazdu sędziów pokoju mógl jednak zarządzić zebranie zjazdu w składzie poszerzonym (np. czterech sędziów gminnych i czterech sędziów pokoju lub nawet wszystkich sędziów okręgu pokojowego) dla rozpatrzenia spraw szczególnej wagi ${ }^{40}$. Udział prokuratora (lub jego pomocnika) na posiedzeniach porządkowych zależał od jego uznania. Dopiero później pojawiły się przepisy dotyczące obligatoryjnego uczestnictwa prokuratora sądu okręgowego na posiedzeniach porządkowych zajmujących się zmianami siedzib sądów gminnych lub budowy rewirów i okręgów sądowych.

$\mathrm{Na}$ posiedzeniach porządkowych rozpoznawano wszystkie sprawy dotyczące organizacji sądownictwa w okręgu pokojowym, m. in. zatwierdzano instrukcje sądowe dla sądów gminnych oraz przygotowywano instrukcje szczególowe dla sędziów pokoju i zjazdu sędziów pokoju, które przesyłano do Ministra Sprawiedliwości $w$ celu zatwierdzenia ${ }^{41}$. Ponadto wydawano wszelkie zarządzenia z zakresu administracji sądowej, których celem było zapewnienie właściwej i nieprzerwanej działalności sądów w okręgu pokojowym oraz podejmowano szereg decyzji natury personalnej, np. wydania świadectw obrońców prywatnych. Zjazd sędziów pokoju działał również jako organ nadzoru i kontroli nad sądami niższymi i urzędnikami sądowymi. Tutaj były kierowane sprawozdania $\mathrm{z}$ działalności sądów gminnych, sędziów

${ }^{37}$ Art. 7 i 45 postanowienia o zastosowaniu...

${ }^{38}$ Potwierdza to orzeczenie departamentów kasacyjnych Senatu Rządzącego z $1867 \mathrm{r}$. mówiące o podstawie do uchylenia wyroku, który zapadł na posiedzeniu zjazdu pod nieobecność sekretarza lub jego pomocnika, Podrecznik dla sq̨ów gminnych..., t. I, s. 91.

${ }^{39}$ Art. 141 ustawy o organizacji władz sądowych...; Patrz szerzej W. Miklas zewski, Rys organizacyi..., s. 74.

40 APL, Zjazd Sędziów Pokoju I okręgu pokojowego guberni lubelskiej [dalej: ZSP 1 okręgu GL] Nariad 5/1901, Prezes zjazdu sẹdziów pokoju [dalej: PZSP] I okręgu guberni lubelskiej do sędziego pokoju I rewiru miasta Lublina z 16 III 1901 r., nfol.

${ }^{41}$ Art. 29 postanowienia o zastosowaniu... oraz art. 74 i 171 ustawy o organizacji władz sądowych... Instrukcje dla sędziów pokoju i dla zjazdu sędziów pokoju układane były przez zjazd w składzie powiększonym, liczącym co najmniej połowę sędziów gminnych i sędziów pokoju okręgu pokojowego. 
pokoju i komorników funkcjonujących przy zjeździe sędziów pokoju. Badano również wyniki $\mathrm{z}$ przeprowadzanych rewizji (kontroli działalności) oraz kontroli finansowych sądów niższych okręgu pokojowego. Przedmiotem posiedzeń porządkowych często były wszelkiego rodzaju skargi i doniesienia na działalność urzędników sądowych: sędziów, komorników i obrońców prywatnych praktykujących przy zjeździe sędziów pokoju ${ }^{42}$. Jeżeli skargi byly zasadne, na tych posiedzeniach zapadały wstępne decyzje o nadaniu biegu sprawie $\mathrm{w}$ trybie postępowania dyscyplinarnego.

3. Początkowo Etat władz sądowych Warszawskiego Okręgu Sądowego z 19 lutego/3 marca 1875 r. przewidywal jedynie 20 zjazdów sędziów pokoju, lecz dodano jeszcze jeden na mocy zatwierdzonego 1/13 czerwca 1876 r. postanowienia Komitetu do spraw Królestwa Polskiego. Każda z dziesięciu guberni Królestwa Polskiego została podzielona na dwa okręgi pokojowe. Oddzielny miejski zjazd sędziów pokoju powstał dla miasta Warszawy.

Zjazd sędziów pokoju I okręgu pokojowego każdej z guberni posiadał siedzibę w stolicy guberni, natomiast siedziby II okręgu pokojowego były umiejscowione $w$ większych miastach powiatowych guberni, położonych w centrum danego okręgu pokojowego (w przypadku guberni lubelskiej był to Zamość). Okręgi pokojowe utworzone w ramach jednej guberni były mniej więcej równe pod względem powierzchni i zaludnienia. W skali natomiast całego Królestwa Polskiego występowały znaczne różnice, zwłaszcza pod względem zaludnienia. W okręgach pokojowych guberni piotrkowskiej $i$ lubelskiej zamieszkiwalo prawie dwukrotnie więcej ludzi niż w okręgach guberni płockiej, lomżyńskiej czy suwalskiej. Natomiast okręgi pokojowe guberni warszawskiej znacząco odbiegały od innych stopniem zurbanizowania. $\mathrm{O}$ ile w I okręgu pokojowym guberni warszawskiej było dziesięć różnej wielkości miast, to w II okręgu guberni kieleckiej leżały tylko dwa. Te czynniki legły również u podstaw przyszłych zmian dotyczących liczby sędziów pokoju i sędziów gminnych w tych okręgach pokojowych.

W trakcie obrad specjalnie powołanej lubelskiej komisji gubernialnej do spraw wprowadzenia reformy sądowej z góry założono, że każdy z okręgów pokojowych (lubelski i zamojski) liczyć będzie pięć powiatów. Jedyną kontrowersyjną sprawą była przynależność powiatów chełmskiego i krasnostawskiego. Pierwszy projekt bazujący na kryterium geograficznym i dogodności połączeń komunikacyjnych zakładał, że powiat chełmski wejdzie

${ }^{42}$ I. G. Szarkow, Mirowoj sudia..., s. 81. Status obrońców prywatnych przy zjeździe sędziów pokoju regulowały najwyżej zatwierdzone $25 \mathrm{~V} / 6$ VI $1874 \mathrm{r}$. przepisy o osobach, mających prawo być pełnomocnikami w sprawach sądowych. Tekst znajduje się w: Ustawach sqdowych obowiqzujacych w gubernijach Królestwa Polskiego..., t. I, Dodatek III, s. 221-229. 
w skład lubelskiego okręu pokojowego, zaś powiat krasnostawski - do zamojskiego okręgu pokojowego. Plan ten został jednak skorygowany przez lubelską komisję gubernialną, gdyż taki podział wykazywał pomiędzy okręgami pokojowymi znaczne dysproporcje pod względem zaludnienia. Dlatego powiat chelmski, jako zamieszkaly przez ludność ruskq wyznania prawosławnego, bliższa obyczajami i tradycja do mieszkańców wschodniej czésici guberni lubelskiej, zaliczono w skład zamojskiego okręgu pokojowego. Tym samym słabiej zaludniony powiat krasnostawski został przyłączony do lubelskiego okręgu pokojowego. Zmniejszono tym samym różnicę pomiędzy okręgami pokojowymi pod względem zaludnienia do liczby 9 tys. mieszkańców (na korzyść I okręgu pokojowego), wobec 19 tys. z pierwszego projektu. Ostateczny projekt podziału guberni lubelskiej na dwa okręgi pokojowe zostal ustalony na posiedzeniu lubelskiej komisji gubernialnej do spraw wprowadzenia reformy sądowej, które odbyło się 31 stycznia/12 lutego $1876 \mathrm{r}$. w godzinach wieczornych ${ }^{43}$. Projekt ten, po zaakceptowaniu przez Ministra Sprawiedliwości, zostal zatwierdzony $17 / 29$ maja 1876 r. ukazem cesarskim z I Departamentu Senatu Rządzącego ${ }^{44}$.

Pierwszy okręg pokojowy guberni lubelskiej składał się z pięciu powiatów: lubelskiego, lubartowskiego, krasnostawskiego, nowoaleksandryjskiego (puławskiego) i janowskiego, wraz z wchodzącymi w ich skład 21 okręgami sądów gminnych (powiat nowoaleksandryjski podzielono na pięć okręgów sądowych, zaś pozostałe powiaty na cztery) i pięcioma rewirami sędziów pokoju. Dwóch rewirowych sędziów pokoju urzędowało w Lublinie, który podzielono na dwa cyrkuły, jeden w Krasnymstawie, zaś dwaj posiadali rewiry złożone z dwóch miast: Janowa i Kraśnika oraz Lubartowa i Lęcznej. Powierzchnia I okręgu pokojowego guberni lubelskiej liczyła 7026 wiorst kwadratowych $\left(7995,6 \mathrm{~km}^{2}\right)$ z 380587 mieszkańcami ${ }^{45}$.

Przez cały okres funkcjonowania modelu sądownictwa rosyjskiego w Królestwie Polskim miała miejsce tylko jedna zmiana dotycząca budowy I okręgu

${ }^{43}$ APL, Lubelski Gubernialny Urząd do spraw Włościańskich [dalej: LGUdsWl] 478; Dziennik posiedzenia LGUdsWł z 31 I 1876 r., k.583-585; LGUdsWł 477, Gubernator lubelski [dalej: GL] do general-gubernatora warszawskiego [dalej: GGW] (bez daty), k. 125-128. Na temat specjalnej lubelskiej gubernialnej komisji do spraw wprowadzenia reformy sądowej i jej składu patrz: A. B ereza, Sady gminne powiatu zamojskiego..., s. 46-49.

44 Zbiór Praw, t. VI, s. 241 i t. IX, s. 103-105; APL, LGUdsWł 477, GGW do GL z 15 V 1876 r., k. 304-306, LGUdsWł 478, Dziennik LGUdsWł z 31 I 1876 r., k. 583-585; Kancelaria GGW do p.o. z 23 VI 1876 r., k.229; Ukaz Senatu Rządzącego z 17/29 V 1876 r., k. 693; LGUdsWł 478; „Lublinskija Gubiernskija Wiedomosti” [dalej: LGW] 1876, dodatek do nr 21.

${ }^{45}$ LGUdsW1 477, Rozpisanie okręgów pokojowych guberni lubelskiej w piśmie GL do GGW (bez daty), k. 125-126; Trudy Warszawskogo Statisticzeskogo Komitieta, wypusk XV, Warszawa 1898, s. 30-39. Na temal zamojskiego zjazdu sẹdziów pokoju patrz: A. B e re za, Zamojski zjazd sędziów pokoju w latach 1876-1915, „Zamojskie Studia i Materiały” 2000, II, z. 1 , s. $13-24$. 
pokojowego guberni lubelskiej. Na mocy ukazu Senatu Rządzącego z 11/23 czerwca 1879 r. przeniesiono cały powiat chełmski (wraz z sẹdzią pokoju miasta Chelma i czterema sądami gminnymi) z II (zamojskiego) okręgu pokojowego do I (lubelskiego) okręgu pokojowego guberni lubelskiej, który tym samym stawał się jednym $\mathrm{z}$ największych w Królestwie Polskim ${ }^{46}$. Po tej zmianie w skład I okręgu pokojowego guberni lubelskiej wchodziło sześciu rewirowych sędziów pokoju i 25 sądów gminnych. Z czasem pojawiły się dodatkowo jeszcze dwa etaty rewirowych sędziów pokoju (w Lublinie i Nowej Aleksandrii) i jeden sąd gminny w powiecie nowoaleksandryjskim.

Poważne zmiany $w$ strukturze sądownictwa pokojowego przewidywano po 1912 r. w związku $\mathrm{z}$ wydzieleniem guberni chelmskiej $\mathrm{z}$ generał-gubernatorstwa warszawskiego ${ }^{47}$. Projekt dotyczący organizacji sądownictwa w guberni chełmskiej i nowej guberni lubelskiej wraz z obszernym uzasadnieniem był przygotowany $w$ Ministerstwie Sprawiedliwości już 24 kwietnia/7 maja 1913 r. i zostal niezwłocznie wniesiony do ciał ustawodawczych. Wbrew panującym opiniom w Ministerstwie Sprawiedliwości (przewidywano wejście ustawy jeszcze w 1913 r.) proces legislacyjny znacznie się przedłużył i trwał $w$ sumie ponad rok. Ustawa o strukturze sądownictwa w guberni chelmskiej i o zmianie etatów niektórych stanowisk sądowych wywołanej utworzeniem tej guberni została zatwierdzona przez cesarza dopiero 12/25 lipca 1914 r., z tym że liczne jej postanowienia dotyczące struktury sądownictwa pokojowego i ogólnego miały być wprowadzone w życie od 1/14 stycznia 1915 r. ${ }^{48}$ Ustawa zakładała zmniejszenie I okręgu pokojowego guberni lubelskiej poprzez wylączenie powiatu chełmskiego i przyłączenie go do nowo utworzonego I okręgu pokojowego nowej guberni chełmskiej. Przewidywano również wzmocnienie etatowe dzięki powołaniu czwartego sędziego pokoju w Lublinie. Projektowano znaczne zasilenie I okręgu pokojowego guberni lubelskiej przez utworzenie 12 nowych sądów gminnych: jednego w powiecie krasnostawskim, dwóch w powiecie lubartowskim, trzech w powiecie lubelskim i aż sześciu nowych sądów gminnych w powiecie janowskim ${ }^{49}$. Plany reorganizacji sądownictwa pokojowego na tych terenach nie zostały

${ }^{46}$ APL, LGUdsWł 478, GL do LGUdsWł z 16 VII 1879 r., k. 804-804v i Kopia ukazu Senatu Rządzącego z 11/23 VI 1879 r., k. 805-807.

${ }^{47}$ Ustawa ,O utworzeniu ze wschodnich części guberni lubelskiej i siedleckiej odrębnej guberni chełmskiej $\mathrm{z}$ wyjęciem jej spod zarządu general-gubernatora warszawskiego" została uchwalona przez Dumę Państwową 14/27 VI 1912 r., zaś sankcję cesarza Mikołaja II uzyskała 23 VI/6 VII 1912 r., SUiRP 1912, nr 128, otdieł pierwyj, s. 1120.

${ }^{48}$ SUiRP 1914, nr 168, otdieł pierwyj, st. 1952, art. XVIII. (APL, ChGUdsWl 119, k. 49-54v). Treść ustawy i jej realizacje przedstawia: A. K o ro bow i cz, Projekt i przygotowania do organizacji sqdownictwa w guberni chelmskiej, „Annales UMCS” 1988, sectio G, vol. XXXV, s. $183-199$.

${ }^{49}$ SUiRP 1914, nr 168, otdieł pierwyj, st. 1952, art. III, IV, V; GSW 1913, nr 24, s. 367. 
jednak nigdy zrealizowane $\mathrm{z}$ powodu wybuchu I wojny światowej, zaś powstanie guberni chełmskiej spowodowało jedynie niewielkie zmiany w funkcjonowaniu sądownictwa pokojowego na styku $z$ organami administracji (np. w zakresie finansowania $)^{50}$.

4. Koszt uposażenia członków i wydatki kancelaryjne lubelskiego zjazdu sędziów pokoju przewidywal Etat wladz sądowych Warszawskiego Okręgu Sądowego z 1875 r. Koszt osobowy lubelskiego zjazdu sędziów pokoju wynosil 4900 rubli rocznie, w tym prezes zjazdu otrzymywal 3 tys. rubli (wynagrodzenie 2500 i koszty delegacji 500), sekretarz zjazdu 600, dwóch komorników urzędujących przy zjeździe po 400 rubli i dwóch woźnych po 225 rubli. Wynagrodzenie dla nich wraz $z$ kwota 300 rubli rocznie przeznaczoną na wydatki kancelaryjne pokrywane były w całości ze Skarbu Państwa. W rzeczywistości, po potrąceniu składki emerytalnej urzędników i opłaty za obowiązkową prenumeratę wydawnictw urzędowych, wypłacano rocznie 4778 rubli $^{\text {sl }}$. Kwota na utrzymanie skladu osobowego rosła wraz z pojawianiem się nowych etatów, powiększeniem wynagrodzenia sądowych urzędników kancelaryjnych oraz zwiększeniem sum przeznaczonych na wydatki kancelaryjne. Należy pamiętać również, że przy lubelskim zjeździe sędziów pokoju funkcjonowal dodatkowy sędzia pokoju.

Największe wątpliwości od samego początku budziła wysokość sumy przeznaczonej na tzw. wydatki kancelaryjne, z których prezes zjazdu musiał pokryć nie tylko koszt materiałów biurowych, ale również opłacić wolnonajemnych pisarzy pracujących $w$ kancelarii zjazdu oraz wszelkie inne wydatki gospodarcze, np. oświetlenie i ogrzanie siedziby zjazdu. Kwota 300 rubli rocznie była stanowczo za niska, jak na tak duże potrzeby, dlatego już ukazem Senatu Rządzącego z 9/21 lipca 1876 r. powiększono ją do wysokości 1 tys. rubli rocznie ${ }^{52}$.

Powaźną sprawą było znalezienie i przygotowanie siedziby lubelskiego zjazdu sędziów pokoju oraz mieszkania dla prezesa zjazdu. Zgodnie z etatem władz sądowych, obowiązek dostarczenia tych lokali obciążał władze miasta, w których zjazd miał wyznaczoną siedzibę ${ }^{53}$. Lubelski zjazd sędziów pokoju początkowo urzędowal w Lublinie przy ulicy Królewskiej pod nr 204, tuż

${ }^{50}$ A. Wr zyszcz, Gubernia chelmska. Zarys ustrojowy, Lublin 1997, s. 97-99, 145-147. APL, Kancelaria Gubernatora Lubelskiego [dalej: KGL] 1913: 21, s. III, Gubernator chelmski do GL z 5 XI 1913 r., nfol.

sl APL, ZSP I okregu GL 27/1876 r., Rozpisanie sum zatwierdzonych w MS na 1876 r. ze Skarbu Państwa na utrzymanie zjazdu sędziów pokoju, k. 14-15, 28. Z funduszy miejskich utrzymywano w Królestiwie Polskim jedynie miejski zjazd sędziów pokoju w Warszawie, uwaga nr 1 do Etatu władz sądowych w Warszawskim Okręgu Sądowym z 19 II/3 III 1875 r.

${ }^{52}$ Zbiór Praw, t. IX, Ukaz Senatu Rządzącego z 9/21 VII 1876 r. o powiększeniu środków kancelaryjnych zjazdów sẹdziów pokoju w guberniach Warszawskiego Okręgu Sądowego, s. 103.

${ }^{53}$ Uwaga 2 do Etatu władz sądowych w Warszawskim Okręgu Sądowym z 19 II/3 III 1875 r. 
obok siedziby wydziału karnego Lubelskiego Sądu Okręgowego ${ }^{54}$. Od samego początku pojawiło się szereg nieporozumień w sprawie rozliczeń pomiędzy miastami okręgu pokojowego i pokrycia kosztów utrzymania pomieszczeń sądowych. Sprawę uregulowało ostatecznie najwyżej zatwierdzone 14/26 marca 1878 r. zdanie Rady Państwa: $O$ uposażeniu kwaterunkowym wladz sadowych Warszawskiego Okregu Sadowego ogłoszone ukazem Senatu Rządzącego z 11/23 kwietnia $1878 \mathrm{r}^{55}$

Na mocy tego aktu prawnego prezesi zjazdów sędziów pokoju otrzymywali dodatek do uposażenia przeznaczony na oświetlenie i ogrzanie mieszkania, fundusze na wynajęcie mieszkania (tzw. płaca kwaterunkowa) i odpowiedniego pomieszczenia dla zjazdu oraz powiększono kwotę na wydatki kancelaryjne zjazdu w celu pokrycia kosztów oświetlenia i ogrzania pomieszczeń sądowych. Sumy te były zróżnicowane ze względu na wielkość i status miasta, w którym zjazd urzędowal. Zasady ustalone $w$ tym akcie $i$ wysokość kwot przeznaczonych na te wydatki (były one powiększane jedynie w drodze uznaniowych decyzji właściwego rządu gubernialnego z powodu wzrostu kosztów utrzymania w mieście) obowiązywały aż do ewakuacji rosyjskiej w czasie I wojny światowej.

W świetle przepisów ukazu Senatu Rządzącego z 11/23 kwietnia 1878 r. wprowadzono dla prezesa zjazdu płacę kwaterunkową, która zastąpiła obowiązek dostarczania mieszkania przez miasto. Mieszkanie prezesa zjazdu sędziów pokoju miało się składać z czterech pomieszczeń, kuchni i przedpokoju ${ }^{56}$. Prezes zjazdu sędziów pokoju w Lublinie otrzymywał na ten cel (wedhug zasad określonych w ukazie) sumę 400 rubli rocznie. $Z$ czasem, na skutek wzrostu kosztów utrzymania w Lublinie, kwota ta stała się niewystarczająca; np. prezes zjazdu lubelskiego T. I. Loszkiejt wynajmowal mieszkanie, za które płacił aż 714 rubli $^{57}$. Dlatego, na mocy postanowienia Lubelskiego Rządu Gubernialnego, kwota przeznaczona na ten cel została powiększona w $1908 \mathrm{r}$. do wysokości 600 rubli rocznie i jej wysokość nie uległa już zmianie do ewakuacji zjazdów sędziów pokoju guberni lubelskiej do Rosji w 1915 r. $^{58}$

W $1878 \mathrm{r}$. ustalono również kwotę wypłacaną z funduszy miejskich na pokrycie kosztów wynajęcia siedziby zjazdu sędziów pokoju. Zgodnie ze

${ }^{54}$ Kalendarz Lubelski na rok zwyczajny 1877 r., R. IX, s. 62.

ss Zbiór Praw, t. XIV, Ukaz Senatu Rządzącego z 11/23 IV 1878 r., s. 249-259; APL, ZSP I okręgu GL 17/1878 Kopia ukazu Senatu Rządzącego z 14/26 IV 1878 r., nfol.

${ }_{56}$ APL, ZSP I okręgu GL 18/1878, Kopia zatwierdzonych rozmiarów pomieszezeń i kwater dla siedzib i urzędników sądownictwa pokojowego z 1877 r., nfol.

${ }_{57}$ APL, RGL A II 1911: 287, PZSP II okregu pokojowego guberni lubelskiej do GL z 29 VII 1911 r., k1 - lv, Dziennik postanowień RGL z 5 VI 1912 r., k. $24-27$.

s8 APL, ZSP I okręgu GL 17/1878, GL w RGL do PZSP I okreggu pokojowego guberni lubelskiej z 17 X 1908 r. i Kopia postanowienia RGL z 7 VII 1908 r., nfol. 
wskazówkami z ukazu Senatu Rządzącego z 11/23 kwietnia 1878 r. siedziba zjazdu powinna się składać co najmniej z sześciu pomieszczeń i przedpo$\mathrm{koju}^{59}$. Był to więc spory lokal, który miał podkreślać rangę zjazdu sędziów pokoju w systemie sądownictwa pokojowego. Na wynajęcie pomieszczeń zjazdu lubelskiego od $1878 \mathrm{r}$. kasa miejska Lublina wypłacała kwotę 630 rubli $^{60}$. Była to wówczas suma wystarczająca, tym bardziej że zjazd sędziów pokoju od 1877 r. wynajmowal sześć pomieszczeń w budynku Natana Millera, na ulicy Poczętkowskiej (dziś ul. Staszica) nr 146, za 600 rubli $^{61}$. Był to dawny pałac Czartoryskich, sprzedany w ręce prywatne i dotychczas dzierżawiony fabryce tabaki i tytoniu ${ }^{62}$; architekturą przypominał pałac Czartoryskich w Puławach, lecz poczynione przeróbki niezwykle go zeszpeciły. Naprzeciwko niego, na rogu ul. Poczętkowskiej i Zielonej, stał budynek w kształcie podkowy (dawny pałac Potockich), zwany Starym Kryminalem, w którym dotychczas urzędowały sądy, a od czasów reformy sądowej utworzono $w$ nim szpital rannych wojskowych ${ }^{63}$. W jednym $\mathrm{z}$ pomieszczeń siedziby zjazdu sędziów pokoju funkcjonował od $1878 \mathrm{r}$. tymczasowy sąd wojskowy w Lublinie, otwarty na podstawie rozkazu głównodowodzącego Warszawskiego Okręu Wojskowego z 25 kwietnia/ 7 maja $1878 \mathrm{r}^{64}$

59 Zbiór Praw, t. XIV, Ukaz Senatu Rządzącego z 11/23 IV 1878 r., art. 1, pkt 5, s. 253. Kopia zatwierdzonych przepisów dotyczących rozmiarów pomieszczeń i kwater dla siedzib i urzędników sądownictwa pokojowego z $1877 \mathrm{r}$. - mówiły o pięciu pomieszczeniach i przedpokoju dla potrzeb zjazdu pokojowego, APL, ZSP I okręgu GL 17/1878, nfol.

60 Zbiór Praw, t. XIV, ukaz Senatu Rządzącego z 11/23 IV 1878 r., art. 1, pkt 2, s. 249.

${ }^{61}$ APL, ZSP I okręgu GL 17/1878, Magistrat miasta Lublina do PZSP I okregu pokojowego guberni lubelskiej z 26 I 1878 r., Kopia pokwitowania PZSP I okręgu pokojowego guberni lubelskiej dla Lubelskiej Kasy Miejskiej z $23 \mathrm{~V} 1878$ r., Kontrakt najmu pomieszczeń dla ZSP I okręgu pokojowego guberni lubelskiej z 1877 r., nfol.; H. G a wa recki, Dwa wrażenia... czyli Lublin jakim byl w roku 1827 i jakim jest w roku 1877 Stanislawa Krzesińskiego, „Rocznik Lubelski” 1958, nr 1, s. 247. Nazwa ulicy pochodziła od klasztoru karmelitanek zwanych też Poczętkami od Kościoła pod wezwaniem Niepokalanego Poczęcia Najświętszej Maryi Panny. Zmiana nazwy ulicy nastąpiła w czasie I wojny światowej $z$ okazji 90-lecia zgonu S. Staszica, Ilustrowany przewodnik po Lublinie ułożony przez M. A. R., cz. 1.., s. 50.

${ }^{62}$ Kalendarz Lubelski na rok zwyczajny 1880 r., R. XII, s. 96, 107; H. G a wa reck i, Porównawczy opis Lublina z lat 1822 i 1889 r. Seweryna Liniewskiego, "Studia i Materiały Lubelskie" 1963, Historia Sztuki, z. 1, 1963, s. 265 i 271; t e nż e, Dwa wrażenia..., s. 235-236. Fabryka tabaki i tytoniu mieściła się tam w latach 1834-1869 (A. K ie rek, Stosunki ekonomiczne miasta Lublina w latach 1815-1870, „Annales UMCS” 1961, sectio G, vol. VIII, s. 328; Inaczej Ilustrowany przewodnik po Lublinie ułożony przez M. A. R., cz. 1..., s. 190 podający rok 1866 jako datę likwidacji fabryki). Dziś jest to siedziba Lubelskiego Towarzystwa Naukowego.

${ }^{63}$ H. G aw a r e ck i, Porównawczy opis Lublina..., s. 266; t e ṅ̇e, Dwa wrażenia..., s. 235-236, 246-247; Ilustrowany przewodnik po Lublinie ulożony przez M. A. R., cz. 2..., s. 190.

${ }^{64}$ APL, ZSP I okręgu GL (bez numeru)/1878, Urząd Wojennego Naczelnika Guberni Lubelskiej do PZSP I okręgu pokojowego guberni lubelskiej z 6 IV 1878 r., nfol. 
Przeznaczenie na wynajęcie siedziby zjazdu lubelskiego kwoty 630 rubli rocznie spowodowało renegocjowanie umowy na korzystniejszych warunkach dla zjazdu. Dzięki temu zjazd w latach 1880-1895 r. funkcjonował w tym samym budynku, zajmując dziewięć pokoi, dwa przedpokoje i $\operatorname{sien}^{65}$.

Od 1895 r. lubelski zjazd sędziów pokoju rozpoczął urzędowanie w budynku Trybunału Koronnego, na Rynku pod nr 1 (na Starym Mieście), zajmując pomieszczenia po wydziale cywilnym Lubelskiego Sądu Okręgowego, który przeniósł się do nowo wybudowanego gmachu przy Krakowskim Przedmieściu $^{66}$. W budynku Trybunału, oprócz zjazdu, urzędował również sędzia pokoju I rewiru w Lublinie (do 1905 r.), wydział hipoteczny u boku tegoż sędziego i funkcjonowały kancelarie dwóch rejentów. Dla potrzeb sądownictwa pokojowego dokonano kilku przeróbek, które nie zawsze były pożyteczne. Przede wszystkim zlikwidowano duży hol dla oczekującej publiczności i znacznie zmniejszono pomieszczenie noszące szumną nazwę gabinetu dla adwokatów przysieglych $i$ prywatnych. W tym maleńkim pokoiku, w którym mogły pracować dwie lub trzy osoby, w czasie posiedzeń zjazdu gromadzić się musiało aż kilkunastu adwokatów i obrońców prywatnych. Ponieważ stanowił on oddzieloną szklanymi drzwiami część dawnego korytarza, dochodził doń gwar z zewnątrz, który utrudniał spokojne skupienie myśli, a samo urządzenie - jedynie dwa lub trzy krzesła - pozostawiało sporo do życzenia ${ }^{67}$.

${ }^{65}$ Kalendarz Lubelski na rok zwyczajny 1882, R. XIV, s. 91; ...na rok zwyczajny 1883, R. XV, s. 86; ...na rok zwyczajny 1886, R. XVIII, s. 88, ...na rok zwyczajny 1887, R. XIX, s. 80 ; ...na rok przestepny 1888 , R. XX, s. 100; ...na rok zwyczajny 1890, R. XXII, s. 100; ...na rok zwyczajny $1891, \mathrm{R}$. XXIII, s. 111 ; ...na rok zwyczajny 1893, R. XXV, s. 100; ...na rok zwyczajny 1894, R. XXVI, s. 88. APL, ZSP I okręgu GL 17/1878, Kontrakty najmu pomieszczeń dla ZSP I okręgu pokojowego guberni lubelskiej: z 1879 r., 1882 r., 1886 r. i z 1890 r.; Magistrat miasta Lublina do PZSP I okręgu pokojowego guberni lubelskiej: z 29 XII 1879 r., z 31 XII 1879 r., 31 VII 1880 r., nfol. W 1889 r. podniesiono czynsz do 900 rubli ze wzglẹdu na potrzeby remontowe siedziby zjazdu sędziów pokoju w Lublinie - GL do PZSP I okręgu pokojowego guberni lubelskiej z 24 VI 1889 r. i Kopia postanowienia RGL z 15 VI 1889 r., nfol.

${ }^{6}$ APL, RGL B I 1892:19c, Kontrakt na budowę Sądu Okręgowego w Lublinie [dalej: SOL] z 10 IX 1892 r., nfol; RGL B I 1892:19a, Prezes SOL do GL z 13 I 1895 r. i Akt przyjęcia i oddania budynku SOL dla prezesa SOL w obecności starszego prezesa Warszawskiej Izby Sądowej [dalej: WIS] tajnego radcy Aristowa... z 1895 r. (data dzienna nieczytelna), nfol.; GSW 1894, nr 47, s. 752. Wiadomości na temat tej planowanej przeprowadzki zjazdu sędziów pokoju I okręgu w Lublinie pojawiały się systematycznie w prasie już od 1891 r. (GSW 1891, nr 19, 307). Nowy okazały budynek Sądu Okręgowego został wybudowany w latach 1892-1894 $\mathrm{i}$ do dziś nieprzerwanie służy potrzebom sądownictwa. Obecnie mieści się $w$ nim Sąd Rejonowy. Patrz A. K o r ob owicz, Sqdownictwo..., s. 85.

${ }^{67}$ Kalendarz Lubelski na rok przestẹpny 1896, R. XXVIII, s. 4-5; Ilustrowany przewodnik po Lublinie ułożony przez M. A. R., cz. 2..., s. 184; GSW 1897, nr 7, s. 108. Dawny pokój palestry (za czasów funkcjonowania w budynku Trybunału Lubelskiego Sądu Okręgowego) został przeznaczony dla sędziów pokoju i sẹdziów gminnych przyjeżdżających na posiedzenia zjazdu. 
Kwoty przeznaczone na wynajęcie mieszkania prezesa zjazdu sędziów pokoju oraz siedziby zjazdu sędziów pokoju sędziego pokrywane były $\mathrm{z}$ funduszy wszystkich miast wchodzących w skład okręu pokojowego. Całą tę sumę dzielono na podstawie postanowienia właściwego rządu gubernialnego, proporcjonalnie do zwykłych dochodów miast wchodzących w skład okręgu pokojowego. $\mathrm{Na}$ analogicznej zasadzie pokrywano koszty wynajęcia kwatery dla dodatkowego sędziego pokoju urzędującego przy zjeździe sędziów pokoju. Cała kwota na pokrycie tych wydatków wyplacana była na ręce prezesa zjazdu sędziów pokoju z kasy miasta, w którym zjazd sędziów pokoju mial swoją stałą siedzibę. Do kasy tej wpływały kwoty z poszczególnych miast okręgu pokojowego, w wysokości określonej $w$ postanowieniu rządu gubernialnego. Jeżeli miasta te nie dysponowały $w$ kasie miejskiej kwotą określoną przez rząd gubernialny, to brakującą sumę ściągano $\mathrm{w}$ drodze składki mieszkańców płacących tzw. podatek kwaterunkow ${ }^{68}$. W praktyce ponad $50 \%$ wszystkich kosztów lubelskiego zjazdu sędziów pokoju pokrywano zawsze z kasy miejskiej Lublina ${ }^{69}$.

Obok omówionych wyżej kosztów kwaterunkowych prezesa i zjazdu sędziów pokoju pokrywanych z funduszy miejskich, przewidziano również specjalne dodatkowe sumy na oświetlenie oraz ogrzanie wynajętych lokali, wypłacane ze Skarbu Państwa. Na oświetlenie i ogrzanie mieszkań prezesów zjazdów w guberni lubelskiej dodano im do uposażenia kwotę w wysokości 100 rubli rocznie, zaś zjazdy sędziów pokoju otrzymały na ten cel sumę w wysokości 150 rubli rocznie, którą zasilono fundusz wydatków kancelaryjnych zjazdu ${ }^{70}$.

Oprócz wydatków związanych z kosztami lokalowymi, powiększano systematycznie wysokość funduszu asygnowanego ze Skarbu Państwa na wydatki kancelaryjne zjazdu, gdyż kwota 1 tys. rubli była niewystarczająca. Związane to było nie tyle $\mathrm{z}$ koniecznością zakupu rosnącej ilości materiałów biurowych, co z wyplatami wynagrodzenia dla zatrudnianych pracowników wolnonajemnych w kancelarii zjazdu ${ }^{71}$. W tym też celu od $1882 \mathrm{r}$. Minister Sprawiedliwości otrzymywał ze Skarbu Państwa dodatkową sumę na powięk-

${ }_{68}$ Zbiór Praw, t. XIV, Ukaz Senatu Rządzącego z 11/23 IV 1878 r., art. 1 pkt 9, 10, 11, s. 255 ; DPKP, t. 68 , Zatwierdzona $31 \mathrm{~V} / 12$ VI 1868 r. ustawa o nowym rozkładzie składki kwaterunkowej $w$ guberniach Królestwa Polskiego, s. 305-311.

${ }^{69}$ APL, ZSP I okręgu GL 17/1878, Kopia postanowienia RGL z 7 VII 1908 r., nfol. - zawiera podział tych kwot na poszczególne miasta I okręgu pokojowego guberni lubelskiej.

${ }^{70}$ Zbiór Praw, t. XIV, Ukaz Senatu Rządzącego z 11/23 IV 1878 r., art. 1 pkt 6 i 8 , s. $253-255$.

${ }^{7}$ APL, ZSP I okręgu GL 1/1908, Spis wynagrodzenia urzędników ZSP I okregu pokojowego guberni lubelskiej w $1908 \mathrm{r}$, nfol. Na tej zasadzie zatrudniano thumaczy przeznaczając na ich opłacenie 400 rubli $z$ funduszu kancelaryjnego. 
szenie wydatków kancelaryjnych wszystkich zjazdów pokojowych w Królestwie Polskim, którą rozdzielał $\mathrm{w}$ zależności od ich potrzeb. W $1882 \mathrm{r}$ była to kwota 5 tys. rubli, zaś od 1887 r. -10 tys. rubli rocznie ${ }^{72}$. Z tej ogólnej sumy oddanej do dyspozycji Ministra Sprawiedliwości lubelski zjazd pokojowy otrzymywal w latach 1882-1886 dodatkową kwotę na „wzmocnienie" wydatków kancelaryjnych w wysokości 250 rubli, zaś od 1887 r. - już 500 rubli. Zdarzały się również okresy, np. w 1894 r., gdy zjazd I okręgu pokojowego guberni lubelskiej otrzymal na „wzmocnienie” środków kancelaryjnych 1200 rubli $^{73}$. Prośby o powiększenie funduszu kancelaryjnego zjazdu prezes wysyłał bezpośrednio do Ministerstwa Sprawiedliwości (do 1896 r.), a potem - na podstawie okólnika Ministra Sprawiedliwości - do starszego prezesa Warszawskiej Izby Sądowej. Od jego uznania zależało uwzględnienie przedstawionych wniosków ${ }^{74}$.

Całkowity koszt utrzymania zjazdu lubelskiego (razem z dodatkowym sędzią pokoju i dodatkami na ogrzanie i oświetlenie siedziby zjazdu oraz kwater prezesa i dodatkowego sędziego pokoju) asygnowany ze Skarbu Państwa w 1894 r. po dokonaniu potrąceń na kapital emerytalny i na urzędowe wydawnictwa wynosi ${ }^{75}$ :

a) koszty osobowe razem $z$ dodatkiem na ogrzanie

kwater

-8004 rubli 75 kopiejek

b) koszty kancelaryjne razem $\mathrm{z}$ dodatkiem na

ogrzanie siedziby i wynagrodzenie thumaczy - 1524 rubli 13 kopiejek

c) koszty wzmacniające środki kancelaryjne zjazdu - 1200 rubli

R a zem

-10728 rubli 88 kopiejek

Po dwudziestu latach koszty utrzymania zjazdu sędziów pokoju guberni lubelskiej uległy zwiększeniu na skutek pojawienia się dwóch nowych pomocników sekretarza zjazdu oraz zwiększenia wynagrodzenia urzędników sądowych w $1908 \mathrm{r}^{76}$ Całkowity koszt utrzymania zjazdu lubelskiego w 1914 r. asygnowany ze Skarbu Państwa wynosił:

72 Zbiór Praw, t. XXXIII, Warszawa 1887, NZZRP z 15/27 XII i 886 r., s. 81; SUiRP 1887, nr 7, st. 69; „Kraj” 1887 , nr 5, s. 11 .

${ }^{73}$ APL, ZSP I okręgu GL 1/1894, Kancelaryjne wydatki ZSP I okręgu pokojowego guberni lubelskiej asygnowane ze Skarbu Państwa w 1894 r., k. 8.

${ }^{74}$ APL, ZSP I okręgu GL 1/1908, Starszy prezes WIS do PZSP I okręu pokojowego guberni lubelskiej z 19 XI 1908 r., nfol.; GSW 1896, nr 4, s. 63.

75 APL, ZSP I okręu GL 22/1895, Koszty utrzymania ZSP I okręgu pokojowego guberni lubelskiej w 1894 r., nfol.; ZSP I okręgu GL 1/1894, Koszty osobowe i wydatki kancelaryjne asygnowane ze Skarbu Państwa w 1894 r., k. 2-8. Do wyliczonej sumy dodać należy jeszcze dodatki dla prezesa zjazdu sędziów pokoju i dodatkowego sędziego pokoju za wysługe lat.

${ }^{76}$ APL, ZSP I okręgu GL 1/1908, MS do PZSP I okręgu pokojowego guberni lubelskiej z 6 X 1908 r., nfol.; SUiRP 1908, nr 106, st. 772 - NZZRP z 3/16 VII 1908 r. 
a) koszty osobowe razem $z$ dodatkiem na ogrzanie kwater

-11212 rubli

b) koszty ancelaryjne razem $\mathrm{z}$ dodatkiem na ogrzanie siedziby i wynagrodzenie thumaczy - 1515 rubli 41 kopiejek

c) koszty wzmacniające środki kancelaryjne zjazdu - 3450 rubli

R a zem - 16177 rubli 41 kopiejek

Wszystkie te kwoty (wraz z dodatkami za wieloletnią służbę) na utrzymanie zjazdów sędziów pokoju guberni lubelskiej przekazywała Lubelska Izba Skarbowa. Pensje dla urzędników sądowych wypłacała w równych częściach co miesiąc, z tym że część wynagrodzenia - tzw. „pieniądze stołowe” wypłacano w styczniu w podwójnej wysokości, zaś dodatki kwaterunkowe dla urzędników - co kwartal ${ }^{77}$.

5. Pierwszoplanową rolę w okręgu pokojowym spełnial prezes zjazdu. Był on stałym urzędnikiem zjazdu, a to wiązało się $\mathrm{z}$ szeregiem samoistnych kompetencji w zakresie administracji sądownictwa. Sam prezes i stopień jego zaangażowania w wykonywanie obowiązków rzutowały na sprawność organizacyjną zjazdu pokojowego, a niekiedy również na kierunek orzecznictwa sądów w podlegającym mu okręgu pokojowym. Najczęściej byli nimi umiarkowani w swoich poglądach doświadczeni prawnicy rosyjscy, wypełniający swoje obowiązki służbowe prawidłowo, nie angażujący się osobiście w politykę narodowościowo-wyznaniową władz administracyjnych. Mieli znaczny wpływ na obsadę urzędów sędziowskich w swoim okręgu pokojowym dzięki nieformalnej rekomendacji do Ministra Sprawiedliwości. Często przy tej czynności starali się kierować dobrem wymiaru sprawiedliwości, polecając osoby dające rękojmię właściwego wypełniania swoich obowiązków na stanowisku sędziego gminnego lub sędziego pokoju. Równie często prezes zjazdu sędziów pokoju w korespondencji do Petersburga popieral kandydatury osób mu znanych lub - co jest charakterystyczne dla systemu rosyjskiego - znajomych czy też spokrewnionych $\mathrm{z}$ innymi sądownikami rosyjskimi. Szczególnie to drugie kryterium nie służyło dobrze poziomowi orzecznictwa sądownictwa pokojowego, gdyż otwierało droge karierowiczom i osobom czasem całkowicie nie nadającym się do piastowania urzędu sẹdziowskiego ${ }^{78}$.

7 APL, ZSP I okregu GL, Nariad 5/1914, Rozpisanie sum przeznaczonych dla MS ze Skarbu Państwa w 1914 r., na utrzymanie ZSP I okręgu pokojowego guberni lubelskiej, k, 43-47. Do wyliczonej sumy dodać należy jeszcze dodatki dla prezesa zjazdu sędziów pokoju i dodatkowego sędziego pokoju za wyshugę lat. Na temat uposażenia urzędników służby cywilnej: A. Bereza, G. S m y k, Stanowisko prawne urzędników..., 256-257.

${ }^{78}$ Wśród prezesów zjazdów sẹdziów pokoju Królestwa Polskiego zdarzały się również osoby niekompetentne. Były nawet przypadki usunięcia prezesa $z$ urzędu ze względu na 
Dla osób prawidłowo wykonujących obowiązki prezesa zjazdu sędziów pokoju, posiadających odpowiednie wykształcenie prawnicze i zasłużonych $w$ pracy $w$ pionie sądownictwa pokojowego, stała otworem kariera do wysokich stanowisk w hierarchii wymiaru sprawiedliwości w Królestwie Polskim ${ }^{79}$. Takie osoby przechodziły na stanowiska prezesów i sędziów pionu sądownictwa ogólnego lub prestiżowy urząd prokuratora przy sądach okręgowych. Były nawet przypadki awansu na najwyższe stanowiska sędziowskie w departamentach Senatu Rządzącego w Petersburgu. Często szybkość awansu zależała od koligacji rodzinnych lub poparcia innych wysoko postawionych urzędników w systemie władz sądowych.

Gubernia lubelska miała szczęście do prezesów zjazdów sędziów pokoju, którzy reprezentowali odpowiedni do sprawowanego urzędu poziom etyczny i przygotowanie prawnicze. Często kończyli oni karierę na najwyższych szczeblach sądownictwa Królestwa Polskiego, a nie brakowało wśród nich również ciekawych indywidualności. Wszystkie stanowiska prezesów zjazdów sędziów pokoju w guberni lubelskiej, podobnie jak w całym Królestwie Polskim, obsadzone były przez Rosjan.

$\mathrm{Na}$ stanowisku prezesa zjazdu sędziów pokoju I okręgu pokojowego w guberni lubelskiej przewinęlo się sześć osób. W ciągu pierwszych dwóch lat od wprowadzenia reformy sądowej nastąpiły aż dwie zmiany na tym stanowisku. Pierwszym prezesem - na etapie jego organizacji - został mianowany A. I. Strojnin i pod jego przewodnictwem lubelski zjazd sędziów pokoju rozpoczął swoją działalność. $\mathrm{Na}$ tym stanowisku pozostal on tylko parę miesięcy, gdyż już $w$ listopadzie 1876 r. został zwolniony ze służby

stronniczość $w$ orzekaniu i daleko posuniętą korupcję lub bulwersujący opinię publiczną i rzucający złe światło na rosyjski wymiar sprawiedliwości tryb życia. Tak było w przypadku prezesów zjazdu sędziów pokoju II okręgu pokojowego guberni suwalskiej: S. T. Ilina (w 1885 r.) i D. L. von Steina (w 1902 r.), prezesa zjazdu sędziów pokoju II okregu pokojowego guberni płockiej W. S. Mingalewa (w 1884 r.) czy prezesa II okręgu pokojowego guberni siedleckiej W. A. księcia Wolkońskiego (w 1902 r.), GSW 1885, nr 47, s. 751; 1886, nr 12, s. 194; Kratkija swiedienija o sudiebnych ustanowlienijach Warszawskogo Sudiebnogo Okruga i diejatielnosti ich za wriemia c 1876 po 1901 god, Warszawa 1901, s. 26; Archiwum Główne Akt Dawnych w Warszawie [dalej: AGAD], Prokurator WIS 2654, nfol. (akta w bardzo złym stanie - A. B.); Pamiatnaja kniżka Warszawskogo Sudiebnogo Okruga [dalej: PK WSO] na 1901 g., s. 108 i na 1902 g., s. 116; H. Ceder ba um, Ze wspomnień aplikanta, Warszawa 1934, s. 13; Rossijskij Gosudarstwiennyj Istoriczeskij Archiw w S. Petersburgie [dalej: RGIAP], F. 1405, op. 545, nr 18598, Rewizja sądownictwa pokojowego II okręgu guberni lubelskiej w 1886 r., k. Iv; AGAD, Prokurator WIS 2543, Prokurator Sądu Okregowego w Lublinie [dalej: PSOL] do Prokuratora WIS z 3 XII 1898 r., k. 5-6.

${ }^{79} \mathrm{Nie}$ wszyscy prezesi zjazdów sędziów pokoju posiadali przygotowanie prawnicze, zwlaszcza w pierwszym okresie działania reformy sądowej. W 1882 r. na 21 prezesów zjazdu siedmiu nie miało wykształcenia prawniczego, A. Suligowski, Nowe sq̨dy w Królestwie Polskim, [w:] Pisma Adolfa Suligowskiego, t. III: Rozprawy z dziedziny prawa, Warszawa 1915, s. 53. 
na własną prośbę ${ }^{80}$. Nie odegrał więc znaczącej roli w kształtowaniu orzecznictwa lubelskiego zjazdu sędziów pokoju, ale na nim spoczął ciężar pierwszych prac organizacyjnych.

O wiele bardziej wyrazistą postacią był jego następca, radca kolegialny Nikołaj Fiedorowicz Iwanienko, dotychczasowy organizator i prezes zjazdu sędziów pokoju II okręgu pokojowego guberni łomżyńskiej. Pozostawał on na stanowisku prezesa $w$ Lublinie nieco ponad rok; $28 \mathrm{kwietnia} / 10$ maja $1878 \mathrm{r}$. został mianowany wicegubernatorem siedleckim ${ }^{81}$. Był to rzadki przypadek w historii Królestwa Polskiego przejścia $\mathrm{z}$ tego urzędu sądowego na tak wysokie stanowisko w administracji gubernialnej.

Nowym prezesem lubelskiego zjazdu sędziów pokoju został dobry prawnik, rejestrator kolegialny Iwan Iwanowicz Riznicz, posiadający opinię czlowieka lagodnego i spokojnego ${ }^{82}$. Wykształcenie odebrał w elitarnym Liceum księcia Bezborodko, zaś doświadczenie nabyl, pracując w pionie sądownictwa już od $1863 \mathrm{r}$. W Królestwie Polskim pojawił się w momencie wprowadzenia reformy sądowej; objął wówczas posadę sędziego pokoju miasta Janowa w I okręgu pokojowym guberni lubelskiej. Funkcję prezesa lubelskiego zjazdu sędziów pokoju pełnił przez dziewięć lat: od 8/20 maja $1878 \mathrm{r}$. do 10/22 czerwca 1887 r., dobrze wykonując swoje obowiązki. Formą wyróżnienia jego zasług dla służby cywilnej były wysokie odznaczenia: św. Stanisława II klasy (w 1883 r.) i św. Anny II klasy (w 1887 r. ) $^{83}$ Jego nominacja stanowiła rzadki przypadek bezpośredniego mianowania na urząd prezesa zjazdu osoby sędziego pokoju, który sądził $w$ tym samym okręgu pokojowym. Polityka personalna w pionie sądownictwa pokojowego najczęściej zakładała

${ }^{80}$ Kratkija swiedienija..., s. 25; APL, ZSP I okręgu GL 15/1876, Prikaz po wiedomstwu Ministierstwa Justicyi of 12 XI 1876 g., $\mathrm{nr} 43$, nfol.

${ }^{81}$ APL, ZSP I okregu GL, 15/1876, Prikaz po wiedomstwu Ministierstwa Justicyi ot 3 XII 1876 g., nr 46, nfol.; ZSP I okręgu GL 17/1878, GGW do Gubernatora Siedleckiego z 1 V 1878 r., nfol.; LGW 1878, nr 18, s. 3 i nr 19, s. 2; Kratkija swiedienija..., s. 25; LGW 1878 , nr 19, s. 2. Na temat rang urzędniczych, patrz: A. Bereza, G. Smyk, Stanowisko prawne urzedników..., s. 248-250, 256-262.

${ }^{82}$ Był siostrzeńcem powieściopisarza Henryka Rzewuskiego, H. Wi e r ci eń s k i, Pamiętniki..., s. 489.

${ }^{83}$ APL, KGL 1876: 164 lit. a, Raport naczelnika janowskiego do GL z 4 VIII 1876 r., nfol.; ZSP I okręgu GL 15/1876, Prikaz po wiedomstwu Ministierstwa Justicyi of 27 V 1876 g., nr 21. Brudnopis informacji sporządzonej dla MS przez PZSP I okręgu pokojowego guberni lubelskiej (bez daty) na temat pođległych mu sędziów pokoju, nfol.; Pamiatnaja Kniżka Lublinskoj Gubierni [dalej: PK LG] na 1877 g., s. 63 i na 1879 g., s. 62; Kratkija swiedienija..., s. 24-25; LGW 1878, nr 23, s. 2; PK WSO na 1879 g., s. 102-103; Spisok czinam Ministierstwa Justicyi $1882 \ldots$, cz. 3, s. 73; GSW 1883, nr 25, s. 400 i z 1887 r., nr 6, s. 115; RGIAP, F. 1405, op. 545, nr 18597, Rewizja sądownictwa pokojowego I okręgu guberni lubelskiej w $1886 \mathrm{r}$., k. 1; GSW 1892, nr 4, s. 63 i nr 15, s. 239 ; „Kraj” 1887 , nr 26, s. 15 ; 1892, nr 1, s. 19; Kalendarz Lubelski na rok zwyczajny 1886, R. XVIII, s. 64 i ...na rok przestepny 1888, R. XX, s. 77 . 
przy nominacji na prezesa zjazdu sędziów pokoju dyslokację do innego okręgu pokojowego Królestwa Polskiego. I. I. Riznicz został w 1887 r. przeniesiony na równorzędne stanowisko prezesa zjazdu sędziów pokoju w I okręgu pokojowym guberni warszawskiej. Urzędowal tam przez pięć lat, aż do śmierci, ciesząc się sympatią podwladnych i osób funkcjonujących przy zjeździe ${ }^{84}$.

Nowym prezesem lubelskiego zjazdu sędziów pokoju został mianowany 24 listopada/6 grudnia 1887 r., pochodzący z guberni grodzieńskiej, radca tytularny Teodor Iwanowicz Łoszkiejt. Ukończył Cesarski Instytut Mikołajewski w Gatczynie, a w służbie cywilnej pozostawał już od $1864 \mathrm{r}$. Prace w wymiarze sprawiedliwości rozpoczął w 1875 r., piastując urząd sędziego pokoju okręgu telszewskiego guberni kownieńskiej, zaś od 1878 r. - sędziego pokoju miasta Błonie w I okręgu pokojowym guberni warszawskiej. Przed objęciem posady prezesa lubelskiego zjazdu sędziów pokoju był jeszcze prawie przez cztery lata (od 10/22 stycznia 1884 r. do 24 listopada/6 grudnia 1887 r.) prezesem zjazdu sędziów pokoju II okręgu pokojowego guberni kieleckiej. W trakcie długiej służby $w$ sądownictwie pokojowym guberni lubelskiej otrzymał range rzeczywistego radcy stanu i bardzo wysokie odznaczenia (w tym order św. Włodzimierza III stopnia i św. Stanisława I stopnia). Jego urzędowanie na stanowisku prezesa zjazdu sędziów pokoju I okręgu pokojowego guberni lubelskiej stanowiło prawie epokę, gdyż pozostawal na nim ponad 22 lata - aż do $1910 \mathrm{r}$. Już $17 / 30$ listopada 1908 r. zostal mianowany przez cesarza honorowym sędzią pokoju w powiecie białostockim guberni grodzieńskiej na trzechlecie 1908-1911, lecz nadal wykonywał obowiązki prezesa lubelskiego zjazdu sędziów. Opuścił to stanowisko dopiero 27 czerwca/10 lipca $1910 \mathrm{r}$. - po otrzymaniu nominacji na członka Sądu Okręgowego w Grodnie, gdzie wkrótce zakończył swoją shużbę ${ }^{85}$.

${ }^{84}$ Prezesem zjazdu sędziów pokoju I okręu pokojowego guberni warszawskiej był w okresie od 10/22 VI 1887 r. do 21 III/2 IV 1892 r.; Kratkija swiedienija..., s. 24 . W 1892 r. tuż przed śmiercią otrzymał rangę rzeczywistego radcy stanu - GSW 1892, nr 4, s. 63 i nr 15 , s. 239 ; „Kraj” 1887 , nr 26 , s. $15 ; 1892$, nr 1, s. 19.

ks W 1888 r. otrzymał range radcy stanu, zaś w 1900 r. rzeczywistego radcy stanu; order św. Włodzimierza III stopnia otrzymał w 1903 r., a order św. Stanisława I klasy - w 1905 r.; APL, ZSP I okręgu GL 1/1887, Prikaz po wiedomstwu Ministierstwa Justicyi ot 24 XI 1887 g., nr 53, Prikaz po wiedomstwu Ministerstwa Justicyi ot 1 I 1888 g., nr 1, MS do PZSP I okręgu pokojowego guberni lubelskiej z $14 \mathrm{~V} 1896$ r., Formularz przebiegu służby rzeczywistego radcy stanu Łoszkiejta z czerwca 1910 r., MS II Departament do ZSP I okręgu pokojowego guberni lubelskiej z 17 I 1903 r., Informacja o osobie, rodzinie i materialnym położeniu PZSP I okręgu pokojowego guberni lubelskiej Łoszkiejta, Spis osób nagrodzonych l I 1905 r. orderami w okręgu pokojowym lubelskiego zjazdu sędziów pokoju, nfol.; ZSP I okręgu GL 10/1907, Spis osób wyznania prawosławnego służących w I okręgu pokojowym guberni lubelskiej i ich rodzin zamieszkujących w Lublinie z 18 IV 1907 r., nfol.; Kratkija swiedienija..., s. 25; GSW 1888, nr 2, s. 30; Kalendarz Lubelski na rok zwyczajny 1890, R. XXII, s. 77. 
W ciągu ostatnich pięciu lat przed wybuchem I wojny światowej zjazd I okręgu pokojowego guberni lubelskiej miał jeszcze dwóch prezesów o podobnym przebiegu służby. Pierwszym z nich był radca stanu Stiepan Teodorowicz Turbaba, który stanowisko objął w 1910 r., mając za sobą 20-letnie doświadczenie pracy w wymiarze sprawiedliwości. Karierę w Królestwie Polskim rozpoczął w 1899 r., gdy z funkcji sędziego miasta Pokrowa guberni włodzimierskiej zostal przeniesiony na stanowisko dodatkowego sędziego pokoju II okręgu pokojowego guberni kaliskiej. Przed objęciem prezesury zjazdu lubelskiego służył jeszcze jako sędzia pokoju miasta Augustowa (1901-1905) w I okręgu pokojowym guberni suwalskiej i XXXIII rewiru miasta Warszawy (1905-1910). Krótko w 1910 r. byl również prezesem zjazdu II okręgu pokojowego guberni warszawskiej. W Lublinie na stanowisku prezesa zjazdu pozostał prawie cztery lata, gdyż w grudniu 1913 r. został mianowany członkiem Warszawskiej Izby Sądowej, co było wspaniałym ukoronowaniem jego kariery prawniczej. Po ewakuacji w $1915 \mathrm{r}$. kierowal przez pewien czas kancelarią i wydziałem tymczasowym Warszawskiej Izby Sądowej w Moskwie ${ }^{86}$.

Drugim był absolwent uniwersytetu w Kijowie, radca kolegialny Władimir Fiedorowicz Sochańskij - ostatni prezes lubelskiego zjazdu sędziów pokoju. Był doświadczonym prawnikiem, mającym za sobą długą służbę w sądownictwie. Podobnie jak jego poprzednik zaczynał w Królestwie Polskim jako dodatkowy sędzia pokoju (od 1907 r. w I okręgu pokojowym guberni kieleckiej), a następnie był sędzią pokoju VII rewiru miasta Warszawy (1911-1913). W maju 1913 r. objął na krótko posadę prezesa zjazdu II okręgu pokojowego guberni suwalskiej. W Lublinie urzędował ponad rok - do momentu ewakuacji sądownictwa w gląb Rosji, w obliczu zbliżającego się frontu działań militarnych I wojny światowej $j^{87}$.

6. Przy zjeździe sędziów pokoju urzędowali również - pozostając w stałej dyspozycji prezesa zjazdu - dodatkowi sędziowie pokoju, którzy nie posiadali

${ }^{86}$ APL, PSOL 58, Prikaz po wiedomstwu Ministierstwa Justicyi ot 3 IV 1899 g., nr 15, nfol.; GSW 1901, nr 16, s. 25; PK WSO: ...na 1901 g., s. 48; ...na 1902 g., s. 106; ...na 1903 g., s. 107; ...na 1906 g., s. 71; ...na 1908 g., s. 71; RGIAP, F.1405, op. 545, nr 16077, k. 35 i 61; APL, ZSP I okręgu GL 5/1914, Starszy prezes WIS do PZSP I okręgu pokojowego guberni lubelskiej z 4 I 1915 r., k. 397; PK WSO ...na 1915 g., s. 4; A. K o r o bow i c z, Sadownictwo..., s. 164

${ }^{87}$ AGAD, WIS 18, Informacja o urzędnikach służących w I okręgu pokojowym guberni lubelskiej sporządzona w 1917 r., k. 44-44v; PK WSO ...na 1908 g., s. 91 ; ...na 1914 g., s. 136; ...na 1915 g., s. 77; RGIAP, F.1405, op. 545, nr 16077, k. 76; APL, LGUdsWl 480, Postanowienie ZSP I okręgu pokojowego guberni lubelskiej z 13 II 1915 r., nfol.; ZSP I okręgu GL 5/1914, Wysokość potrąceń $\mathrm{z}$ pensji urzędników ZSP I okręgu pokojowego guberni lubelskiej na kapitał emerytalny Cesarstwa z marca 1914 r., k. 112-113. 
własnego rewiru i kancelarii. W polityce etatowej władz rosyjskich urząd dodatkowego sędziego pokoju - specyficzny dla Królestwa Polskiego - miał dwojaki charakter. Na urzędzie tym często znajdowali się zdolni i doskonale przygotowani sędziowie, którzy pozostawali tam chwilowo, oczekując na dalszy awans $w$ strukturze sądownictwa. Przenoszono na to stanowisko również sędziów, którzy dopuścili się w swoich dotychczasowych rewirach różnego rodzaju nadużyć będących przyczyną oburzenia miejscowej spoleczności. W celu utrzymania „prestiżu rosyjskiego wymiaru sprawiedliwości” przenoszono takiego urzędnika na stanowisko dodatkowego sędziego pokoju w innej guberni Królestwa Polskiego, pozbawiając go nie tylko kontaktu ze znaną mu ludnością, lecz tym samym ograniczając również do minimum możliwość jego samodzielnego orzekania.

Zauważalna jest różnica w szybkości rotacji na stanowisku dodatkowego sędziego pokoju w latach osiemdziesiątych i dziewięćdziesiątych XIX stulecia i 15-letnim okresem wieku XX, do czasów I wojny s̉wiatowej. W latach 1876-1900 zmiany nie były tak szybkie i spotykamy w tym okresie dodatkowych sędziów pokoju, którzy dłużej piastowali swoje stanowisko. Od początku XX w. częstotliwość zmian na tym stanowisku znacznie wzrosła; traktowano je wówczas często jako swoistą „poczekalnię" na otrzymanie wlasnego rewiru sądowego lub zashużony, oczekiwany awans na stanowisko wyższe. Wynikało to także $\mathrm{z}$ pojawiającej się tendencji zasilania sądownictwa ogólnego doświadczonymi sądownikami z pionu pokojowego.

Przy zjeździe sędziów pokoju I okręgu guberni lubelskiej dodatkowy sędzia pokoju zostal przewidziany już w etacie z 1875 r. Przez 40 lat funkcjonowania rosyjskiego modelu sądownictwa w Królestwie Polskim na stanowisku tym przewinęło się 12 osób.

Pierwsi dwaj dodatkowi sędziowie pokoju lubelskiego zjazdu sędziów pokoju piastowali swój urząd krótko. Pierwszy, mianowany od 1 lipca 1876 r., to dotychczasowy kandydat do posad sądowych przy Saratowskim Sądzie Okręgowym, rejestrator kolegialny Modest Lwowicz Borwikowskij. Pod koniec roku opuścil gubernię lubelską, gdyż został rewirowym sędzią pokoju w okręgu skwirskim guberni kijowskiej ${ }^{88}$. Zastąpił go dotychczasowy rewirowy sędzia pokoju z Warszawy, absolwent uniwersytetu w Petersburgu, sekretarz kolegialny Aleksandr Aleksandrowicz Welsberg. Jednak już w kwietniu 1878 r. został przeniesiony na posadę rewirowego sędziego pokoju okręgu krzemienieckiego guberni wolyńskiej ${ }^{89}$.

${ }^{88}$ APL, ZSP I okręgu GL 15/1876, Prikaz po wiedomstwu Ministierstwa Justicyi ot $27 \mathrm{~V}$ 1876 g., nr 21; Brudnopis informacji sporządzanej dla MS przez PZSP I okręgu pokojowego guberni lubelskiej na temat sędziów pokoju, nfol.; Kalendarz Lubelski na rok zwyczajny 1877, R. IX, s. 63; Spisok czinam Ministierstwa Justicyi 1882..., cz. 3, s. 57; PK LG na 1877 g., s. 62.

89 APL, ZSP I okręgu GL 23/1877, Prikaz po wiedomstwu Ministierstwa Justicyi ot 23 IV $1878 \mathrm{~g}$, nr 16, k. 17; Formularz przebiegu służby dodatkowego sędziego pokoju Aleksandra Welsberga, k. 23-28; Spisok czinam Ministierstwa Justicyi $1882 \ldots$, cz. 3, s. 7. 
Kolejnym i zarazem najdłużej urzędującym dodatkowym sędzią pokoju w I okręu pokojowym był radca dworu Aleksandr Władimirowicz Prorwicz, posiadający wyższe wykształcenie prawnicze po ukończeniu uniwersytetu w Moskwie. Na tym stanowisku służył od 1878 r. do 1891 r., kiedy to zostal zwolniony ze służby na własną prośbę, z powodu pogarszającego się stanu zdrowia. Byl typowym urzędnikiem sądowym, bez aspiracji na dalszy awans, zakładającym już w momencie nominacji pozostanie na tej spokojnej posadzie. Obejmując stanowisko dodatkowego sędziego pokoju, mial za sobą długi, 28-letni staż w służbie cywilnej, w tym niecałe pięć ostatnich lat na stanowisku rewirowego sędziego pokoju w okręgu starokonstantynowskim guberni wołyńskiej. Często wyjeżdżał za granicę do ciepłych wód ze względu na chroniczny reumatyzm. Tuż przed odejściem ze służby, gdy jego stan zdrowia ulegl nagłemu pogorszeniu (operacja prawego oka), otrzymał range radcy stanu ${ }^{90}$.

Innych dodatkowych sędziów pokoju można podzielić na trzy grupy. Pierwszą stanowily osoby dysponujące uniwersyteckim wykształceniem prawniczym, dla których stanowisko to bylo krótkim przystankiem w dalszej karierze prawniczej, ukoronowaniem której były posady sędziów sądów okręgowych. Do nich zaliczyć należy: radcę stanu Pawła Pietrowicza Truskowskiego (1895 r.), radcę kolegialnego Josifa Andriejewicza Ignatiewa (w latach 1903-1904) i radcę dworu Nikifora Pietrowicza Pejcza (w latach 1906-1909) ${ }^{91}$. P. P. Truskowskij, wcześniej sędzia śledczy powiatu zamojskiego i rewirowy sędzia pokoju w Krasnymstawie, później sędzia pokoju nowo utworzonego III rewiru miasta Lublina, został w 1904 r. członkiem Piotrkowskiego Sądu Okręgowego ${ }^{92}$. J. A. Ignatiew, wcześniej sędzia śledczy do

${ }^{90}$ APL, ZSP I okręu GL 57/1878, Pismo radcy dworu Prorwicza do ZSP I okregu pokojowego guberni lubelskiej z 27 VI 1878 r., k. 1. i ZSP Starokonstantynowskiego okręgu pokojowego wołyńskiej guberni do PZSP I okręgu pokojowego guberni lubelskiej z 25 VI 1878 r., k. 3; Prikaz po wiedomstwu Ministierstwa Justicyi ot 14 V 1878 g., nr 19, k. 4; Formularz przebiegu służby Aleksandra Prorwicza zestawiony 15 IV 1892 r., k. 17-20; Zaświadczenie dr Władysława Krajewskiego z Teplic-Schonau o dolegliwościach sędziego A. Prorwicza, k. 46, Świadectwo lekarskie z 20 VI 1890 r., Swiadectwo Odeskiej Miejskiej Lecznicy Okulistycznej z 1 VIII 1890 r.; Ukaz Senatu Rządzącego z 16/28 III 1892 r. stwierdzający nadanie Prorwiczowi rangi radcy stanu od dnia $15 / 27$ VII 1880 r., nfol; ZSP I okręgu GL 3/1891, Prikaz po wiedomstwu Ministierstwa Justicyi ot 16 X 1891 g., $\mathrm{nr} 44$, nfol.; SOL 1107, Protokół z posiedzenia porządkowego SOL z 13 I 1896 r., k. 3-4; PK WSO na 1879 g., s. 102 ; LGW 1878 , nr 23, s. 2.

9i PK WSO: na 1895 g., s. 60; ...na 1904 g., s. 106; ...na 1905 g., s. 110 ; na 1908 g., s. 107; Spisok czinam wiedomstwa Ministierstwa Justicyi 1913 goda..., s. 858; PK WSO na 1915 g., s. 72; GSW 1904, nr 41, s. 656; Kalendarz Lubelski na rok zwyczajny 1907 r., R. XXXIX, s. 82 .

${ }_{92}$ APL, KGL 1884: 55, Prikaz po wiedomstwu Ministierstwa Justicyi of 29 XII 1883 g., nr 56, k. 1v; ZSP I okregu GL 15/1885, Informacja na temat służby P. P. Truskowskiego; LGW 1884, nr 2, s. 2; GSW 1884, nr 13, s. 212; 1895, nr 12, s. 190; PK WSO na 1894 g., 
spraw poważniejszych przy Suwalskim Sądzie Okręgowym i rewirowy sędzia pokoju w Janowie, później rewirowy rewirowy sędzia pokoju miasta Augustowa, w 1914 r. zostal czlonkiem Łomżyńskiego Sądu Okręgowego ${ }^{93}$. Ostatni z nich - N. P. Pejcz, po pięcioletnim urzędowaniu jako dodatkowy sędzia pokoju (pierwsze dwa lata 1904-1906 przy zamojskim zjeździe sędziów pokoju), został w 1909 r. mianowany na stanowisko członka Lubelskiego Sądu Okręgowego ${ }^{94}$.

Drugą grupę tworzyły osoby, które osiągnęły w swojej karierze co najwyżej stanowisko rewirowego sędziego pokoju. Wśród nich należy wymienić: W. A. Krapiwina, T. A. Janowicza oraz M. A. Chomicza. Sekretarz gubernialny Wasilij Arkadiewicz Krapiwin, dodatkowy sędzia przy lubelskim zjeździe sędziów pokoju w latach 1892-1895, potem krótko sędzia pokoju II rewiru miasta Lublina jeszcze w 1895 r. przeszedł na stanowisko dodatkowego sędziego pokoju przy zjeździe sędziów pokoju I okręgu guberni warszawskiej, na którym pozostal przez sześć lat. W jego przypadku wykształcenie na poziomie skończonego gimnazjum w Tule nie dawało już wtedy możliwości dalszego awansu na szczeblach sądownictwa Królestwa Polskiego ${ }^{95}$. Radca dworu Teodor Andriejewicz Janowicz, wcześniej sędzia śledczy przy Sądzie Okręgowym w Symferopolu, później od 1893 r. rewirowy sędzia pokoju miasta Zamościa, który został przeniesiony w 1896 r. na stanowisko dodatkowego sędziego pokoju I okręgu guberni lubelskiej pozostal na tej posadzie dhugo, jak na warunki guberni lubelskiej, bo prawie osiem lat - do $1903 \mathrm{r}$. Wtedy objąl stanowisko dodatkowego sędziego pokoju przy warszawskim miejskim zjeździe sędziów pokoju i zaraz potem - na kilka lat - urząd sędziego pokoju XXV rewiru miasta Warszawy ${ }^{96}$.

s. 59; PK LG na 1885 g., s. 59; GSW 1895, nr 12, s. 190; 1896, nr 19, s. 302; Kalendarz Lubelski na rok zwyczajny: 1897 , R. XXIX, s. 61; ...1899, R. XXXI, s. 83, ..1902 r., R. XXXIV, s. 71; APL, PSOL 75, Prikaz po wiedomstwu Ministierstwa Justicyi ot 18 II 1904 g., nr 10, nfol.; GSW 1904, nr 11, s. 173; PK WSO na 1903 g., s. 71; PK LG na 1897 g., s. 219.

${ }_{93}$ GSW 1899, nr 24, s. 381; 1903, nr 52, s. 822; PK WSO na 1903 g., s. 71; PK LG na 1901 g., s. 189; GSW 1903, nr 52, s. 822; PK WSO ...na 1904 g., s. 106; ...na 1913 g., s. 94; ...na 1915 g., s. 64 .

${ }^{94}$ GSW 1904, nr 41, s. 656; PK WSO na 1905 g., s. 110 ; ...na 1908 g., s. 107; Kalendarz Lubelski na rok zwyczajny 1907 r., R. XXXIX, s. 82; Spisok czinam wiedomstwa Ministierstwa Justicyi 1913 goda..., s. 858; PK WSO na 1908 g., s. 107; ...na 1915 g., s. 72; GSW 1904 , nr 41, s. 656; A. B ereza, Zamojski zjazd sędziów..., s. 19.

${ }^{9}$ GSW 1892, nr 17, s. 272; 1895, nr 12, s. 190; „Kraj” 1892, nr 16, s. 23; Kalendarz Lubelski na rok zwyczajny 1894, R. XXVI, s. 64; PK WSO na 1895 g., s. 59; ...na 1895 g., s. 59; GSW 1895, nr 50, s. 797; Kalendarz Lubelski na rok zwyczajny 1897, R. XXIX, s. 61; PK LG na 1895 g., s. 216.

${ }_{96}$ GSW 1893, nr 36, s. 632; 1896, nr 19, s. 302; PK WSO na 1894 g., s. 62; PK LG na 1894 g., s. 22l; GSW 1896, nr 19, s. 302; 1903, nr 36, s. 569; Kalendarz Lubelski na rok 
Radca dworu Michaił Antonowicz Chomicz, który po krótkim - nie liczącym nawet całego roku - urzędowaniu na stanowisku rewirowego sędziego pokoju miasta Krasnegostawu, został w 1910 r. przeniesiony na stanowisko dodatkowego sędziego pokoju I okręgu pokojowego guberni lubelskiej. Pozostał na nim przez trzy lata, aby w 1913 r. - tuż przed śmiercią - objąć na moment II rewir miasta Lublina ${ }^{97}$.

Trzecią grupą byli Rosjanie, którzy - podobnie jak wcześniej wymieniony A. W. Prorwicz - traktowali stanowisko dodatkowego sędziego pokoju jako „ciepłą posadkę" do emerytury. Wśród nich znaleźli się również tacy, którzy na poważniejszy awans liczyć nie mogli (zbyt niskie wykształcenie lub nadużycia na innych stanowiskach) i karierę urzędniczą kończyli na tym lub analogicznym stanowisku w innej guberni. Do nich zaliczyć należy: sekretarza kolegialnego Konstantyna Iwanowicza Panczenko oraz radce kolegialnego Alipija Jakowlewicza Walickiego. Pierwszego przeniesionego z posady sędziego rewirowego miasta Szydłowca na krótko do Lublina w 1891 r., aby w następnym roku mógł objąc stanowisko dodatkowego sędziego pokoju przy zjeździe sędziów pokoju I okręgu pokojowego guberni radomskiej. Drugim byl dotychczasowy rewirowy sędzia pokoju w Międzyrzecu, przeniesiony na posadę dodatkowego sędziego pokoju w 1905 r., aby już w roku następnym zakończyć służbę ${ }^{98}$. Należy jednak zaznaczyć, że nie oznacza to, aby obowiązki dodatkowego sędziego pokoju, przy poważnie obciążonym sprawami lubelskim zjeździe sędziów pokoju, były mniejsze niż rewirowego sędziego pokoju. Świadectwem tego jest historia rewirowego sędziego pokoju Krasnegostawu radcy stanu Osipa Jarosławowicza Onacewicza. W okresie swojej służby w Krasnymstawie został on powołany w marcu 1909 r. na stanowisko dodatkowego sędziego pokoju przy lubelskim zjeździe sędziów pokoju. Po krótkim okresie uznano jednak, że nie sprawdza się na tym stanowisku i w kwietniu 1910 r. został ponownie przeniesiony do Krasnegostawu".

zwyczajny 1898, R. XXX, s. 74, ...1901, R. XXXIII, s. 77; ...1903, R. XXXV, s. 66; Żurnat Ministierstwa Justicyi, 1902, R. 8, nr 1, s. 37; GSW 1903, nr 36, s. 569; PK WSO na 1904 g., s. $69 ;$...na 1906 g., s. 71.

${ }_{97}$ APL, ZSP I okregu GL, Dzienniki posiedzeń 33/1909, Dziennik posiedzenia z $27 \mathrm{~V}$ 1909 r., nfol.; RGIAP, F. 1405, op. 545, nr 16077, k. 14, 30-31, 60, 65; PK WSO na 1910 g., s. 115; PK LG na 1910 g., s. 191; PK WSO na 1912 g., s. 78; GSW 1913, nr 13, s. 196. Spisok czinam wiedomstwa Ministierstwa Justicyi 1913 goda.., s. 864.

${ }^{98}$ GSW 1892, nr 1, s. 15; nr 14, s. 224; PK WSO na 1895 g., s. 46; PK WSO na 1904 g., s. $155 ;$...na 1906 g., s. 107.

99 RGIAP, F. 1405, op. 545, nr 16077, k. 13, 30-31, 52; APL, ZSP I okręgu GL, Dzienniki posiedzeń 24/1909, Dziennik posiedzenia z 17 IV 1909 r., nfol.; ZSP I okręgu GL 307/1909, PZSP I okręgu pokojowego guberni lubelskiej do byłego dodatkowego sẹdziego pokoju, obecnego sędziego pokoju miasta Krasnegostawu z 7 IV 1910 r., nfol.; „Prawitielstwiennyj Wiestnik" 1910, $\mathrm{nr}$ 69; Spisok czinam wiedomstwa Ministierstwa Justicyi 1913 goda..., s. 689; GSW 1912, nr 39, s. 599; PK LG na 1907 g., s. 179; ...na 1911 g., s. 197. 
Ostatnim dodatkowym sędzią pokoju był mianowany w 1913 r. dotychczasowy sekretarz Warszawskiej Izby Sądowej radca tytularny Aleksiej Michałowicz Fieoktistow. Pozostał na tym stanowisku aż do ewakuacji rosyjskich sądów guberni lubelskiej w $1915 \mathrm{r}^{100}$

Ze względu na zakres obowiązków była to odpowiedzialna i niezbędna funkcja, zwłaszcza $w$ okręgach pokojowych o znacznym wplywie spraw sądowych. Dodatkowy sędzia pokoju urzędowal przy zjeździe sędziów pokoju, pozostając stale do dyspozycji prezesa zjazdu, który określał zakres jego obowiązków. Należało do nich uczestnictwo w posiedzeniach zjazdu oraz wykonywanie szeregu poleceń prezesa zjazdu, mających na celu wykonanie nadzoru nad funkcjonowaniem sądownictwa $w$ okręgu pokojowym. Na mocy postanowienia prezesa zjazdu był często delegowany do rewirów sądowych, w których sędzia był nieobecny lub urząd wakowal. Wykonując obowiązki rewirowego sędziego pokoju, dodatkowy sędzia pokoju korzystał z jego siedziby i funduszy kancelaryjnych potrzebnych na wynajęcie pisarzy ${ }^{101}$. Niekiedy otrzymywal zadanie pomocy rewirowemu sędziemu pokoju, jeżeli w jego rewirze nagromadzila się zbyt duża liczba spraw zaległych. W takich wypadkach zjazd sędziów pokoju regulowal zasady współpracy pomiędzy tymi sędziami, gdyż dodatkowy sędzia pokoju musiał korzystać $\mathrm{z}$ obsługi kancelarii rewirowego sędziego pokoju. W praktyce wydawał on rezolucję na aktach sprawy i wskazywał termin, w którym kancelaria miała przygotować wszystkie formalności, po czym sprawa wracala ponownie do dodatkowego sędziego pokoju, w celu wydania wyroku. Jedynie, gdy rewirowy sędzia pokoju nie orzekał w swojej siedzibie, dodatkowy sędzia pokoju mógł samodzielnie korzystać z jego pomieszczeń sądowych ${ }^{102}$.

Dodatkowy sędzia pokoju wypełniał także obowiązki prezesa zjazdu sędziów pokoju, gdy urząd wakował oraz gdy prezes wyjeżdżał na urlop lub osobiście przeprowadzal rewizję sądownictwa w podległym okręgu

${ }^{100}$ RGIAP, F. 1405, op. 545, nr 16077, k. 61; AGAD, WIS 18, Informacja o urzędnikach służących w I okregu pokojowym guberni lubelskiej sporządzona w 1917 r., k. $48-48 \mathrm{v}$; PK WSO na 191.5 g., s. 77.

${ }^{101}$ Np. APL, ZSP I okręgu GL 35/1899, Polecenie PZSP I okręgu pokojowego guberni lubelskiej dla dodatkowego sędziego pokoju Janowicza z 30 VI 1899 r., nfol.

${ }^{102}$ APL, ZSP I okręu GL 57/1878, Sędzia pokoju I rewiru miasta Lublina do PZSP I okręgu pokojowego guberni lubelskiej z 16 II 1882 r., k. 74-74v; Dziennik posiedzeń ZSP I okręgu pokojowego guberni lubelskiej z 21 II 1882 r., k. 75-76; Sędzia pokoju I rewiru miasta Lublina do PZSP I okręgu pokojowego guberni lubelskiej z 7 VI 1882 r., k. 90-90v; Dziennik posiedzeń ZSP I okręgu pokojowego guberni lubelskiej z 22 VIII 1882 r., k. 91; Dziennik posiedzeń ZSP I okręgu pokojowego guberni lubelskiej z 21 XI 1882 r., k. 100-100v; Dodatkowy sędzia pokoju do ZSP I okręgu pokojowego guberni lubelskiej z 14 IV 1883 r., k. $105-108$. 
pokojowym ${ }^{103}$. Było to odpowiedzialne zadanie, wymagające często dobrego przygotowania prawniczego, a wszelkie potknięcia były natychmiast wytykane. Krótki okres pelnienia obowiązków prezesa zjazdu przez A. W. Prorwicza pod koniec 1887 r., przed przyjazdem nowo mianowanego T. I. Loszkiejta, wystarczył, aby Senat Rządzący zareagował ukazem na bałagan i brak nadzoru nad kancelarią. Ostra reakcja Senatu Rządzącego nastąpiła, gdy otrzymał on w trybie kasacyjnym wyrok lubelskiego zjazdu sędziów pokoju, bez podpisów sędziów uczestniczących $w$ posiedzeniu ${ }^{104}$.

W I okręgu pokojowym guberni lubelskiej dodatkowy sędzia pokoju obarczany był zawsze (w różnych okręgach pokojowych praktyka była w tym zakresie zróżnicowana) przez prezesa zjazdu poleceniem przeprowadzenia kontroli finansów sądów okręgu pokojowego, z wyników której składał raport na posiedzeniu porządkowym zjazdu. Rewizję finansów sądownictwa $w$ poszczególnych powiatach przeprowadzał on $z$ udziałem miejscowego rewirowego sędziego pokoju lub sędziego gminnego $z$ tego (lub sąsiedniego) powiatu ${ }^{105}$.

7. Obsługe strony technicznej prac zjazdu sędziów pokoju zapewniała kancelaria zjazdu. Nad sprawnością pracy kancelarii czuwał sekretarz zjazdu sędziów pokoju, któremu podlegali wszyscy pracujący tam urzędnicy sądowi i wolnonajemni kanceliści. Przy lubelskim zjeździe sędziów pokoju guberni lubelskiej przewidziano jeden etat sekretarza zjazdu sędziów pokoju $i$ stan ten nie uległ zmianie do $1915 \mathrm{r}$.

Zakres obowiązków sekretarza zjazdu i liczba podległych mu kancelistów rosły proporcjonalnie do wpływu spraw. Dlatego pojawił się etat pomocnika sekretarza zjazdu sędziów pokoju. Mógł on zastępować sekretarza zjazdu, którego obecność na posiedzeniu zjazdu była obligatoryjna. Tym samym nieobecność sekretarza zjazdu nie blokowała od tej pory działalności zjazdu sędziów pokoju. Pierwszy pomocnik sekretarza zjazdu sędziów pokoju pojawił się w $1878 \mathrm{r}$. na etacie tymczasowym, zaś od $1882 \mathrm{r}$. na etacie stałym w lubelskim zjeździe sędziów pokoju ${ }^{106}$. Bardzo duży napływ spraw

103 APL, ZSP I okręgu GL 307/1909, PZSP I okręgu pokojowego guberni lubelskiej do dodatkowego sędziego pokoju Onacewicza z 30 IX 1909 r., nfol.

${ }^{104}$ APL, ZSP I okręgu GL 57/1878, Ukaz Senatu Rządzącego z 13 X 1888 r., k. 127-128.

105 APL, ZSP I okręgu GL 34/1903, Cyrkularz ZSP I okręgu pokojowego guberni lubelskiej do sędziów pokoju i sẹdziów gminnych z 23 I 1903 r., nfol.; PSOL 156, ZSP I okręgu pokojowego guberni lubelskiej do PSOL z 30 III 1899 r., nfol.; PSOL 163; ZSP I okręgu pokojowego guberni lubelskiej do PSOL z 25 IV 1901 r., nfol. Porównaj: A. B e r e z a, Zamojski zjazd sędziów..., s. 18.

${ }^{106}$ APL, ZSP I okręgu GL 61/1878, PZSP I okręgu pokojowego guberni lubelskiej do MS $z 2$ VIII 1878 r. i Starszy prezes WIS do PZSP I okręgu pokojowego guberni lubelskiej z 3 XII 1878 r., nfol. Pierwszym pomocnikiem sekretarza przy ZSP I okręgu pokojowego guberni lubelskiej był dotychczasowy pisarz sądu gminnego III okręgu powiatu nowoaleksan- 
sądowych na początku XX w. spowodował reorganizację pracy lubelskiego zjazdu sędziów pokoju, który podzielił się na dwa wydziały i został wzmocniony etatowo poprzez ustanowienie w 1909 r. drugiego, zaś w 1913 r. - trzeciego pomocnika sekretarza zjazdu ${ }^{107}$.

$\mathrm{Na}$ urzędach tych następowała szybka rotacja personalna, gdyż traktowano je jako naturalne zaplecze kadrowe dla innych instytucji pokojowych w ramach okręgu pokojowego. Dotychczasowi sekretarze zjazdów sędziów pokoju lub ich pomocnicy często przechodzili na stanowiska sędziów gminnych (z nominacji Ministra Sprawiedliwości), sekretarzy powiatowych wydziałów hipotecznych, komorników lub pisarzy sądów gminnych. Niekiedy sami rezygnowali $\mathrm{z}$ posady rządowej, poświęcając się zawodowi obrońcy prywatnego przed sądami pionu pokojowego.

Szybka rotacja na tych stanowiskach dotyczyła zwłaszcza urzędników rosyjskich. Na przykład sekretarz kolegialny Konstantin Iwanowicz Jankiewicz, dotychczasowy sędzia gminny II okręgu powiatu radzyńskiego guberni siedleckiej, został w 1907 r. mianowany sekretarzem lubelskiego zjazdu sędziów pokoju, w 1908 r. zostal z nominacji Ministra Sprawiedliwości sędzią gminnym II okręgu, zaś od 1913 r. - IV okręgu powiatu chełmskiego. Nie będąc pewnym nominacji, postarał się w 1909 r. o wydanie świadectwa obrońcy prywatnego ${ }^{108}$.

Urząd sekretarza zjazdu sędziów pokoju był dostępny dla Polaków głównie $\mathrm{z}$ powodu brak odpowiednio przygotowanych kadr rosyjskich i małej atrakcyjności tego stanowiska dla przybywających do Królestwa Polskiego Rosjan. W lubelskim zjeździe sędziów pokoju w latach 1876-1915 na 18 sekretarzy zjazdu było dziewięciu Rosjan, najczęściej przez krótki okres.

Na przełomie XIX i XX w. ustaliła się praktyka obejmowania funkcji sekretarza, przez dotychczasowego pomocnika sekretarza zjazdu sędziów pokoju, który nabywał doświadczenie pracując u boku swojego poprzednika. W ten sposób stanowisko to objęło pięciu sekretarzy lubelskiego zjazdu pokojowego $^{109}$.

dryjskiego Oktawiusz Muszyński, który zaraz potem poprosił o wydanie świadectwa obrońcy prywatnego - APL, ZSP I okręgu GL 68/1879, Postanowienie PZSP I okręgu pokojowego guberni lubelskiej z 1 VI 1882 r., k. 10 i Dziennik posiedzenia porządkowego z 25 IX 1882 r., k. 15. Zbiór Praw, t. XXII, NZZRP z 2/14 XI 1882 r., s. 277-279; LGW 1882, nr 49, s. 2.

107 GSW 1910, nr 16, s. 254.

${ }^{108}$ APL, ZSP I okręgu GL 317/1907 Formularz przebiegu służby K. Jankiewicza z 1914 r., k. 8-14 i Swiadectwo obrońcy prywatnego z 9 V 1909 r., k. 42.

${ }^{109}$ Sekretarzami lubelskiego zjazdu sędziów pokoju byli kolejno: Józef Iwanowicz Nowicki (1876-1877), Julian Kozłowski (1877), Jan Markiewicz (1877-1878), Mikołaj Huskowski (18781880), Józef Kozłowski (1880-1883), Michał Dulemba (1884-1887), Jewgienij Grigoriewicz Sikorskij (1887-1888), Tomasz Szmigielski (1888-1896), Władysław Olszewski (1896-1897), Adam Laparewicz (1897-1898), Michaił Nikołajewicz Szangtaj (1898-1900), Aleksandr Nikołajewicz Fedorowskij (1900-1902), Edmund Basiewicz (1902-1906), Julian Osipowicz Charłampowicz (1906-1907), Konstantin Iwanowicz Jankiewicz (1907), Pawel Iwanowicz Borowik 
Spośród sekretarzy w lubelskim zjeździe sędziów pokoju na uwagę zasługują dwie postacie: J. I. Nowicki oraz T. Szmigielski. Przedstawiciel katolickiej szlachty $\mathrm{z}$ guberni witebskiej Józef Iwanowicz Nowicki - pierwszy sekretarz zjazdu na mocy postanowienia prezesa zjazdu I okręgu pokojowego guberni lubelskiej z 20 maja/1 czerwca 1876 r. (oczywiście z dniem 1 lipca 1876 r.) - w ciągu roku pełnienia odpowiedzialnej funkcji sekretarza zjazdu nabyl sporo doświadczenia, które $\mathrm{w}$ połączeniu $\mathrm{z}$ gimnazjalnym wyksztalceniem dało mu później możliwość długoletniej shużby na urzędzie sędziego gminnego w powiatach chetmskim i nowoaleksandryjskim ${ }^{110}$.

Tomasz Szmigielski, który najdłużej pełnił tę funkcję w czasach prezesury T. I. Loszkiejta, chociaż nie ukończył żadnej szkoły, obowiązki swoje wykonywał prawidłowo, pozostając na stanowisku sekretarza przez siedem lat - od 1888 r. do 1896 r. Dzięki nabytemu doświadczeniu w pracy na stanowisku sekretarza został prywatnym obrońcą w I okręgu pokojowym. Jednocześnie, jako jedyny prywatny obrońca $z$ Lublina, mial od 1896 r. prawo występowania przed Warszawską Izbą Sądową, a od 1906 r. - również przed Sądem Okręgowym w Lublinie. Uprawnienia te utrzymał aż do ewakuacji sądownictwa rosyjskiego $z$ Królestwa Polskiego w czasie I wojny światowej ${ }^{111}$.

Do grona urzędników należących do obsługi kancelaryjnej lubelskiego zjazdu sędziów pokoju zaliczyć możemy thumaczy. Na stanowisko to powoływano osoby spośród niższych urzędników kancelaryjnych administracji rosyjskiej lub kancelistów zatrudnionych $w$ siedzibie zjazdu ${ }^{112}$. Początkowo przewidziano jeden etat thumacza, zaś od 1904 r. pojawił się drugi. Często w celach oszczędnościowych prezes zjazdu sędziów pokoju powierzal funkcję thumacza jednemu z pisarzy wolnonajemnych pracujących $w$ kancelarii zjazdu, który otrzymywal $\mathrm{z}$ tego tytułu dodatek do wynagrodzenia ${ }^{113}$.

(1908-1910), Władimir Aleksandrowicz Pigulewskij (1910), Antoni Miller (1910-1911), Stanisław Aktabowski (1911-1913), Julian Mazurek (1913-1915) i Jan Aktabowski (1815).

${ }^{110}$ APL, ZSP I okręgu GL o służbie Józefa Iwanowicza Nowickiego (brak okładek i sygnatury), Formularz przebiegu słuźby byłego sędziego gminnego V okręgu powiatu nowoaleksandryjskiego zestawiony w lutym $1913 \mathrm{~g}$, nfol.; Kalendarz Lubelski na rok zwyczajny 1877, R. IX, s. 62.

in Kalendarz Lubelski na rok zwyczajny 1890, R. XXII, s. 77; ...1891, R. XXIII, s. 90; PK WSO na 1894 g., s. 59; ...na 1896 g., s. 62; PK LG na 1889 g., s. 67; PK WSO: na 1899 g., s. 13,$67 ;$...na 1908 g., s. 48, 106, 110 ; ...na 1915 g., s. 7. Uprawnienie występowania w charakterze obrońcy prywatnego przed Warszawską Izbą Sądową było wyjątkowym przywilejem dla paru osób (np. trzy w 1899 r.). Bardzo rzadko pojawiała się na tej posadzie osoba spoza Warszawy.

${ }^{112}$ APL, ZSP I okręgu GL 67/1879, ZSP I okręgu pokojowego guberni lubelskiej do byłego pisarza janowskiego urzędu powiatowego do spraw poboru wojskowego Siemiona Ptaszyńskiego z 3 X 1878 r., k. 1; ZSP I okręgu GL Nariad 399, Sprawka o przyznaniu kanceliście Władysławowi Szejdalowi dodatku z tytułu wykonywanych obowiązków tłumacza w lubelskim zjeździe sędziów pokoju, k. 4.

${ }^{113}$ PK WSO na 1903 g., s. 215; ...na 1904 g., s. 215; APL, ZSP I okregu GL 43/1879, ZSP I okręgu pokojowego guberni lubelskiej do Napoleona Bieniaszewicza z 31 I 1877 r., k. 2-2v. 
Pozostałą rzeszą pracowników kancelaryjnych była grupa osób zatrudnionych na podstawie umowy najmu ushug, opłacanych $\mathrm{z}$ funduszu kancelaryjnego zjazdu sędziów pokoju. Początkowo wystarczała pomoc dwóch pisarzy $\mathrm{w}$ zjeździe, lecz wraz $\mathrm{z}$ rosnącym nawałem pracy kancelaryjnej liczba ich szybko ulegała powiększeniu. Jeszcze w 1899 r. lubelski zjazd sędziów pokoju zatrudniał pieciu pomocników kancelaryjnych, lecz rok później - $\mathrm{z}$ uwagi na rosnące obciążenie sprawami sądowymi - liczba ich gwałtownie wzrosła. W latach 1900-1915 liczba pracowników wolnonajemnych w kancelarii lubelskiego zjazdu sędziów pokoju wahała się od ośmiu do dziesięciu, w okresie 1905-1906 było ich nawet 14, lecz już w roku 1907 powrócono do poprzedniego zatrudnienia. Było to związane $\mathrm{z}$ ogólnym spadkiem liczby spraw wpływających do sądów pionu pokojowego Królestwa Polskiego. Dopiero w 1911 r. zatrudniono 12 pracowników kancelaryjnych i liczba ich utrzymała się na tym poziomie aż do momentu ewakuacji sądów Królestwa Polskiego w gląb Rosji ${ }^{114}$.

Wśród kancelistów lubelskiego zjazdu sędziów pokoju nie było w ogóle osób mających status urzędnika służby cywilnej ${ }^{115}$. Pojawiły się natomiast kobiety, które na mocy rozporządzenia Ministra Sprawiedliwości z 2/15 listopada 1900 r. mogły być zatrudniane na stanowiskach kancelaryjnych ${ }^{116}$.

Wszystkie pisma, postanowienia, rezolucje, wyroki i ich kopie pisane były ręcznie. Pierwsza maszyna do pisania pojawiła się $w$ zjeździe lubelskim dopiero w 1898 r. Pismo ręczne dominowało jeszcze przez kilka lat w aktach sądowych, gdyż zakup większej liczby maszyn przekraczał możliwości finansowe zjazdu. Najtańsza maszyna do pisania Blikens kosztowała 80 rubli, a więc tyle co wynagrodzenie miesięczne dwóch lub trzech kancelistów $w^{117}$.

114 PK WSO: na 1899 g., s. 189; ...na 1900 g., s. 239; ...na 1901 g., s. 237; ...na 1902 g., s. 239 ; ...na 1903 g., s. 215 ; ...na 1904 g., s. 215 ; ...na 1905 , s. 215 ; ...na 1906 g., s. 215 ; ...na 1907 g., s. 215 ; ...na 1908 g., s. 215 ; ...na 1910 g., s. 233 ; na 1911 g., s. 195 ; ...na 1914 g., s. $225 ;$...na 1915 g., s. 175.

115 W 1901 r. W skali Królestwa Polskiego na liczbę 104 zatrudnionych kancelistów 12 miało status urzędniczy $(11,5 \%)$, zaś w 1915 r. na 150 już 24 (16\%) - Kratkija swiedienija..., s. 11; PK WSO na 1915 g., s. 174-175.

116 APL, ZSP I okręgu GL 390: 1912, Prośba maszynistki A. M. Gawłowskiej do PZSP I okręgu pokojowego guberni lubelskiej z 2 X 1914 r., nfol. Rodzaje prac, które moźna powierzac kobietom $w$ kancelarii, i warunki pracy oraz zasad przyjęcia do pracy określało rozporządzenie MS z $2 / 15$ XI 1900 r. o zatwierdzeniu przepisów tymczasowych co do dopuszczenia kobiet do zajęć w instytucyach podległych Ministeryum Sprawiedliwości - SUiRP 1900, nr 125, st. 2751; GSW 1901, nr 4, s. 50.

117 APL, ZSP I okręgu GL 43/1899, Kancelaria Starszego prezesa WIS do PZSP I okręgu pokojowego guberni lubelskiej z 19 I 1898 r.; Zamówienie przez PZSP I okręgu pokojowego guberni lubelskiej w Fabryce Gerlacha w Warszawie maszyny do pisania Blikens z 15/27 11898 r., nfol. 
Sekretarzom zjazdu służbowo podlegali również pozostający na etacie woźni sądowi ${ }^{118}$. W każdym zjeździe sędziów pokoju guberni lubelskiej było dwóch woźnych sądowych. Liczba etatów nie uległa zmianie do 1915 r., lecz $w$ obliczu znacznie większego obciążenia lubelskiego zjazdu sędziów pokoju, od 1910 r. zaczęto mianować jednego pozaetatowego woźnego opłacanego $z$ funduszy kancelaryjnych zjazdu ${ }^{119}$. Stanowisko woźnego obsadzane było przez Polaków, którzy nie mieli możliwości pracy na innych bardziej prestiżowych urzędach $w$ pionie sądownictwa pokojowego. Mimo niskiego wynagrodzenia zawsze było sporo chętnych, gdyż ta etatowa posada gwarantowała pewną stabilizację życiową. Ponadto zdarzały się odosobnione przypadki mianowania woźnego przez prezesa zjazdu na inny urząd, np. pisarza sądu gminnego lub thumacza ${ }^{120}$.

8. Przy zjeździe sędziów pokoju urzędowali również komornicy - jako urzędnicy sądowi. Od 1876 r. przy lubelskim zjeździe sędziów pokoju funkcjonowalo dwóch komorników etatowych i ich liczba nie uległa zmianie. Wobec tak niewielkiej liczby etatów pojawil się problem usprawnienia egzekucji rosnącej liczby wyroków sądowych wydawanych przez sądy pionu pokojowego. Zaradzono temu, powołując komorników pozaetatowych, którzy nie pobierali stałej pensji, lecz korzystali $\mathrm{z}$ wynagrodzenia za wykonywane czynności egzekucyjne według ustalonej taksy ${ }^{121}$. Od $1887 \mathrm{r}$. przy lubelskim zjeździe pojawiło się dodatkowo dwóch komorników pozaetatowych. Liczba ta nie uległa zmianie przez bardzo długi okres i dopiero w ciągu ostatnich pięciu lat przed wybuchem I wojny światowej liczba komorników pozaetatowych została powiększona do czterech osób ${ }^{122}$.

${ }^{118}$ W przypadku odmowy wykonania polecenia przez woźnego, sekretarz zjazdu składał raport na ręce prezesa, któremu podlegali dyscyplinarnie wszyscy urzędnicy zjazdu. APL, ZSP I okręgu GL 34/1876, Raport sekretarza zjazdu do PZSP I okręgu pokojowego guberni lubelskiej z 1 XI 1876 r., k. 3.

${ }^{119}$ PK WSO na 1915 g., s. 175.

${ }^{120}$ APL, ZSP I okręgu GL 34/1877, Postanowienie ZSP I okręgu pokojowego guberni lubelskiej z 3 VI 1888 r., nfol.; ZSP I okręgu GL 207/1892, Postanowienia ZSP I okręgu pokojowego guberni lubelskiej z 16 XI 1892 r., nfol.; ZSP I okręgu GL 190/1891, Postanowienie ZSP I okręgu pokojowego guberni lubelskiej z 16 XI 1894 r., nfol.; ZSP I okręgu GL 165/1888, Wypis z postanowienia ZSP I okręgu pokojowego guberni lubelskiej z 30 VI $1889 \mathrm{r}$., Postanowienie PZSP I okręgu pokojowego guberni lubelskiej z I XII $1890 \mathrm{r}$., nfol

${ }^{12 i}$ Zbiór Praw, t. XXXIII, 1887 - pierwsze półrocze, NZZRP z 17/29 XI 1886 r., s. 11; SUiRP 1887, nr 2, st. 12; „Kraj” 1887, nr 2, s. 10.

${ }^{122}$ PK WSO: na 1910 g., s. 116; ...na 1911 g., s. 76; ..na 1912 g., s. 79; ...na 1913 g., s. $79 ;. . . n a 1914$ g., s. 84; ...na 1915 g., s. 78. Mogły zdarzyć się przypadki, że liczba komorników etatowych była mniejsza niż przewidywał to etat zjazdu sędziów pokoju, zaś liczba komorników pozaetatowych - nieco wyższa. Np. w 1914 r. przy zjeździe sędziów pokoju I okregu guberni lubelskiej był 1 komornik etatowy, a 5 pozaetatowych. Był to stan tymezasowy, gdyż w świetle art. 301 i 308 ustawy o organizacji sq̨downictwa..., komornik 
Miejsca urzędowania komorników w okręgu pokojowym określał prezes właściwego zjazdu sędziów pokoju, z tym że jeden $\mathrm{z}$ nich musiał urzędować w miejscu siedziby zjazdu sędziów pokoju ${ }^{123}$. W I okręgu pokojowym guberni lubelskiej komornicy urzędowali najczęściej w Lublinie, a po przyłączeniu powiatu chełmskiego (w $1879 \mathrm{r}$.) jeden $\mathrm{z}$ nich (chociaż nie zawsze) - w Chełmie. Sytuacja ta nie uległa zmianie, gdy pojawili się komornicy pozaetatowi. Dopiero pod koniec XIX w. prezes zjazdu wyznaczał miejsce urzędowania jednego $z$ komorników pozaetatowych w Janowie lub Kraśniku, zaś w ostatnich latach przed wybuchem I wojny światowej - jeszcze w Krasnymstawie ${ }^{124}$. Dla celów egzekucyjnych okręg pokojowy został podzielony na rewiry komorników. W latach dziewiẹćdziesiątych jeden $\mathrm{z}$ komorników etatowych obsługiwał Lublin, drugi powiaty lubartowski i nowoaleksandryjski, natomiast powiaty lubelski i janowski stanowily rewir jednego z komorników pozaetatowych, zaś drugi komornik pozaetatowy obshugiwal powiaty chelmski i krasnostawski ${ }^{125}$.

Pracę komorników kontrolowal zjazd sędziów pokoju na posiedzeniach porządkowych. Komornicy byli zobowiązani do corocznego przedstawiania swoich ksiąg czynności urzędowych, na podstawie ustawy o postępowaniu cywilnym sądowym ${ }^{126}$. Na forum zjazdu rozpatrywane były skargi na działalność komorników. Liczba ich była zastraszająco duża, lecz w większości były one calkowicie bezzasadne ${ }^{127}$.

Urząd komornika wykazywał niezwykłą stabilność i w dużym stopniu obsadzony był przez Polaków. Najdłużej urzędującym komornikiem przy lubelskim zjeździe sędziów pokoju był radca tytularny Albert Ryży. Pełnił

dopuszczony do pełnienia obowiązków urzẹdowych mógł być zatwierdzony na tym stanowisku dopiero po upływie co najmniej roku. Sytuacja uległa wyjaśnieniu w momencie, gdy jeden $z$ komorników pozaetatowych został zatwierdzony - po upływie wskazanego terminu - na urząd komornika etatowego przy zjeździe sędziów pokoju.

${ }^{123}$ Art. 61, 62, 305 i 306 ustawy o organizacji sądownictwa...

${ }_{124}$ Kalendarz Lubelski na rok przestepny 1880, R. XII, s. 107; ...na rok zwyczajny 1883, R. XIII, s. 102; ...na rok zwyczajny 1886, R. XVIII, s. 87; ...na rok zwyczajny 1891, R. XXV, s. 111.

${ }^{125}$ Kalendarz Lubelski na rok zwyczajny 1893, R. XXV, s. 36.

126 Przykłady takich sprawozdań znajdują siẹ w APL, ZSP I okręgu GL: 59/1884; 21/1888; 16/1892; 33/1909 (A. Ryżego); 33/1909 (A. O. Lebiedińskiego).

${ }_{127}$ APL, ZSP I okręgu GL Dzienniki posiedzeń 24/1909, Dziennik posiedzenia z 17 IV 1909 r., nfol.; Dzienniki posiedzeń 33/1909, Dziennik posiedzenia z 27 V 1909 r., nfol.; Dzienniki posiedzeń 37/1909, Dziennik posiedzenia z 19 VI 1909 r., nfol.; Dzienniki posiedzeń 39/1909, Dziennik posiedzenia z 6 VII 1909 r., nfol.; Dzienniki posiedzeń 43/1909, Dziennik posiedzenia z 28 VIII 1909 r., nfol.; Dzienniki posiedzeń 47/1909, Dziennik posiedzenia z 24 IX 1909 r., nfol.; Dzienniki posiedzeń 65/1909, Dziennik posiedzenia z 30 XI 1909 r., nfol.; Dzienniki posiedzeń $84 / 1909$, Dziennik posiedzenia z 30 XII 1909 r., nfol.. Podaje tylko dane z posiedzen porządkowych z 1909 r. dla przedstawienia liczby skarg na czynności komorników. Zaznaczam, że na każdym posiedzeniu rozpoznawano po kilka, a nawet kilkanaście skarg osób prywatnych. 
swoje obowiązki w Lublinie, od momentu wprowadzenia reformy sądowej - do 1910 r. ${ }^{128}$ Niewiele ustępował mu stażem jego kolega - drugi komornik etatowy w Lublinie - Emil Błażejowski, który urzędował przez 23 lata (1884-1907) ${ }^{129}$. Wśród komorników pozaetatowych wyróżniają się prawosławni: Antoni Florianowicz Laskarzewski i Nikołaj Fiedorowicz Brujak. Pierwszy z nich byl komornikiem pozaetatowym w latach 1887-1907, urzędującym początkowo w Lublinie, potem krótko - od 1892 r. do 1898 r. - w Chełmie, zaś na końcu $w$ Kraśniku ${ }^{130}$. Drugi natomiast rozpoczął jako komornik pozaetatowy w Chełmie, lecz po siedmiu latach, w 1907 r. przeniósł się do Lublina. Tutaj otrzymał w 1911 r. nominacje na komornika etatowego, ale urząd ten piastowal od następnego roku w Krasnymstawie ${ }^{131}$.

9. Wybuch I wojny światowej zakłócił funkcjonowanie lubelskiego zjazdu pokojowego. Ofensywa austriacka rozpoczęta pod koniec sierpnia 1914 r. (bitwy pod Kraśnikiem i Tomaszowem) oraz realne zagrożenie Lublina spowodowały zawieszenie $15 / 28$ sierpnia działalności lubelskiego zjazdu sędziów pokoju ${ }^{132}$. Początkowe powodzenie wojsk austriackich zniweczyla potężna wrześniowa kontrofensywa rosyjska we wschodniej Galicji. Austriacy zostali zmuszeni do opuszczenia całej Lubelszczyzny, na której terenach już we wrześniu wznowiło działalność sądownictwo pokojowe ${ }^{133}$. Zjazd funkcjonował jeszcze kilka miesięcy, lecz tryb pracy uległ znacznemu zahamowaniu. Wynikało to $z$ trudności dojazdu stron do siedziby sądu, ograniczenia wydatków ze Skarbu Państwa $\mathrm{z}$ uwagi na wprowadzone oszczędności oraz poboru do wojska osób pracujących w kancelarii zjazdu ${ }^{134}$.

${ }^{128}$ Kratkija swiedienija..., s. 58; PK WSO na 1910 g., s. 116; LGW 1877, nr 23, s. 10; 1902, nr 29, s. 20.

129 PK WSO na 1906 g., s. 107; ...na 1907 g., s. 108; APL, ZSP I okręgu GL 27/1902, LGW 1902, nr 29, s. 21, nfol.

${ }^{130}$ PK WSO na 1898 g., s. 61; ...na 1906 g., s. 107.

${ }^{131}$ LGW 1913 nr 202, s. 6; PK WSO na 1907 g., s. 108; ...na 1908 g., s. 108; ...na 1912 g., s. 79 .

${ }^{132}$ RGIAP, F. 1405, op. 545, nr 16077, Telegram PZSP I okręgu pokojowego guberni lubelskiej do MS, k. 87; A. Kor obowicz, Sqdownictwo..., s. 158.

133 J. Lewandowski, Królestwo Polskie wobec Austro-Wegier 1914-1918, Warszawa 1986, s. 37; tenże, Austro-Wegry wobec sprawy polskiej w czasie I wojny światowej. Poczq̨tki zarzqudu okupacyjnego w Królestwie, PH 1975, t. LXVI, s. 392; APL, ZSP I okregu GL Nariad 127, Świadectwo wydane przez PZSP I okregu pokojowego guberni lubelskiej dla sędziego pokoju Lubartowa z 28 V 1915 r., k. 380-381; SOL 1121, PZSP II okręgu pokojowego guberni lubelskiej do starszego prezesa WIS z 6 XI 1914 r., k. 5-5v i Sędzia pokoju miasta Tomaszowa do ZSP II okręgu pokojowego guberni lubelskiej z 21 II 1915 r., k. 17.

${ }^{13+}$ Oprócz wolnonajemnych kancelistów zmobilizowani do wojska zostali dwaj pomocnicy sekretarzy i jeden woźny zjazdu sędziów pokoju I okręgu pokojowego guberni lubeiskiej - APL, ZSP I okręgu GL Nariad 5/1914, Pisma pomocników sekretarzy zjazdu I. F. Aktabowskiego i A. S. Mazurka oraz woźnego G. Szewczyka do PZSP I okręgu pokojowego guberni lubelskiej z 18 VII 1914 r., k. 3-5. 
W maju 1915 r. front działań militarnych ponownie zaczął się zblizać do terenów guberni lubelskiej. Decyzją głównodowodzącego III armią, na przełomie czerwca i lipca, po raz drugi ewakuowano sądownictwo pokojowe guberni lubelskiej i chelmskiej. Wyjechali prezes, wszyscy sędziowie pokoju oraz rosyjscy sędziowie gminni. $\mathrm{Na}$ miejscu pozostali sędziowie gminni narodowości polskiej oraz znaczna część niższego personelu kancelaryjnego ${ }^{135}$.

$\mathrm{Na}$ terenie Cesarstwa lubelski zjazd sędziów pokoju utrzymal szczątkowe struktury w postaci kancelarii i stale urzędującego prezesa zjazdu. Kancelaria zjazdu sędziów pokoju I okręgu guberni lubelskiej działała w Niżnim Nowogrodzie na Powołżu, zaś sam prezes lubelskiego zjazdu sędziów pokoju Sochańskij przebywał w Kazaniu przy ul. Bułak, pod nr 16 (wkrótce do Kazania przeniosła się także kancelaria) ${ }^{136}$. Działalność prezesa zjazdu sędziów pokoju ograniczała się do utrzymania korespondencji z Ministerstwem Sprawiedliwości i załatwiania spraw personalnych urzędników pionu pokojowego rozrzuconych po całej Rosji. Dotyczyły one najczęściej spraw finansowych urzędników, tzn. wyplaty wynagrodzenia oraz przyznania diet i zasilków ${ }^{137}$.

Po rewolucji marcowej w 1917 r. -- gdy perspektywa powrotu władz rosyjskich na ziemie polskie była już nierealna - rozpoczęto likwidację instytucji sądowych ewakuowanych $\mathrm{z}$ Królestwa Polskiego. Zadanie to

${ }^{135}$ A. K or obowic z, Saqdownictwo..., s. 162. Lublin został opuszczony przez sądy w dniu 4 VII 1915 r. - Rkps Wojewódzkiej Biblioteki Publicznej im. H. Lopacińskiego w Lublinie [dalej: WBPwL], nr 1845, s. 34. Podstawą prawną ewakuacji w 1915 r. było zatwierdzone 20 VIII / 2 IX 1914 r. rozporządzenie Rady Ministrów regulujące zasady wywozu mienia państwowego, instytucji rządowych, urzędników i ich rodzin w przypadku zagrożenia wojennego - SUiRP z 1914 r., nr 242, otdieł I, st. 2325. Spośród 26 sędziów gminnych I okręgu pokojowego guberni lubelskiej wyjechało tylko dwóch prawosławnych Rosjan - AGAD, WIS 18, Informacja o urzędnikach służących w I okręgu pokojowym guberni lubelskiej z 1917 r., k. $21-41$.

${ }^{136}$ APL, ZSP I okręgu GL 317/1907, Niżnonowogrodzki Inspektor Więziennictwa do PZSP I okręgu pokojowego guberni lubelskiej z 15 IV 1917 r., k. 157; ZSP I okręgu GL Nariad 405, PZSP I okręgu pokojowego guberni lubelskiej do starszego prezesa Moskiewskiej Izby Sądowej z 21 VI 1917 r., k. 107; PSOL 89, Adresy ewakuowanych zjazdów sędziów pokoju z 5 X 1915 r. zestawione w Wydziale Porządkowym II Departamentu MS, nfol. W wykazie podane są adresy wszystkich zjazdów sędziów pokoju.

${ }^{137}$ APL, ZSP I okręgu GL Nariad 367, K. Skotnicki do PZSP I okręgu pokojowego guberni lubelskiej z 15 III 1916 r., k. 52-53; ZSP I okręgu GL Nariad 434, Prośba kancelisty Ignacego Reja do PZSP I okręgu pokojowego guberni lubelskiej z 17 VII 1916, k. 13; ZSP I okręgu GL Nariad 405, Sędzia pokoju III rewiru miasta Lublina do PZSP I okręgu pokojowego guberni lubelskiej z 29 XII 1915 r., k. 57; ZSP I okręgu GL Nariad 259, Prośba woźnego Piotra Świszczewskiego do PZSP I okręu pokojowego guberni lubelskiej z $28 \mathrm{X}$ 1915 r., k. 35; ZSP I okręgu GL Nariad 403, Pisarz sądu gminnego Nikołaj Aleksandrowicz Karczewski do PZSP I okręgu pokojowego guberni lubelskiej z 10 III 1916 r., k. 21; ZSP I okręgu GL Nariad 344, Pisarz sądu gminnego Adam Władysławowicz Łaniewskij do PZSP 
powierzono Komisji Likwidacyjnej Królestwa Polskiego, na czele z adwokatem Aleksandrem Lednickim.

W tym samym czasie większość Polaków związana $\mathrm{z}$ działalnością sądownictwa pokojowego guberni lubelskiej uczestniczyła na miejscu, wspólnie z adwokatami i notariuszami, w działalności komitetów obywatelskich, a potem $w$ organizowaniu zrębów nowego sądownictwa pod okupacją austriacką ${ }^{138}$. W obsadzie sądów królewsko-polskich w latach 1917-1918 spotkać możemy wielu dawnych sędziów gminnych, sekretarzy wydziałów hipotecznych, obrońców prywatnych, a także sekretarzy zjazdów. Stanowili oni naturalne zaplecze kadrowe dla nowo powołanych sądów pokoju. Liczna grupa obrońców prywatnych, dawnych niższych urzędników sądowych pionu pokojowego, a zwłaszcza sekretarzy lub pomocników sekretarzy lubelskiego zjazdu pokojowego zapełniła etaty pisarzy hipotecznych przy sądach pokoju (np. Władysław Olszewski), komorników (np. Julian Mazurek) lub objęła posady notariuszy (np. Tomasz Szmigielski) ${ }^{139}$. Weryfikuje to w pewnym stopniu utarty pogląd, że nowa organizacja sądownictwa królewsko-polskiego nie mogła liczyć na kadry wywodzące się z ,rosyjskiego sądownictwa pokojowego".

I okręgu pokojowego guberni lubelskiej z 23 I 1917 r., k. 36; ZSP I okręgu GL Nariad 382, PZSP I okręgu pokojowego guberni lubelskiej do Zarządu Policji w Nowej Bucharze z 17 XI 1916 r., k. 16.

${ }^{138} \mathrm{Na}$ temat losów komitetów i organizacji sądów obywatelskich patrz: J. L e wa n d ow ski, Królestwo Polskie..., s. 71, te n ż e, Sqdownictwo w Królestwie Polskim..., s. 228-233; Organizacja Sqdów Obywatelskich uchwalona przez Lubelski Okregowy Komitet Obywatelski, Lublin 1915, s. 1-4; Rkps WBPwL, nr 1845, k. 84-85v.

139 Dziennik Urzędowy Ministerstwa Sprawiedliwości z 1918 r., nr 13, s. 409, 411, i z 1919, nr 2, s. 94, nr 3, s. 127-128. 